\title{
Dharmamegha in yoga and yogācāra: the revision of a superlative metaphor
}

\author{
Karen O'Brien-Kop ${ }^{1}$
}

Published online: 9 May 2020

(C) The Author(s) 2020

\begin{abstract}
The Pātañjalayogaśāstra concludes with a description of the pinnacle of yoga practice: a state of samädhi called dharmamegha, cloud of dharma. Yet despite the structural importance of dharmamegha in the soteriology of Pātañjala yoga, the śāstra itself does not say much about this term. Where we do find dharmamegha discussed, however, is in Buddhist yogācāra, and more broadly in early Mahāyāna soteriology, where it represents the apex of attainment and the superlative statehood of a bodhisattva. Given the relative paucity of Brahmanical mentions of dharmamegha in the early common era, Patañjali appears to adopt this key metaphor from a Mahāyāna context — and to revise its primary meaning from fullness to emptiness. This article traces the early elaborations of dharmamegha in Buddhist texts, and, drawing on conceptual metaphor theory, lays out four arguments that each, in part, accounts for the stark contrast in how classical yoga and yogācāra employ the superlative metaphor of dharmamegha.
\end{abstract}

Keywords Yoga $\cdot$ Yogasūtra $\cdot$ Patañjali $\cdot$ yogācāra $\cdot$ Conceptual metaphor . Yogācārabhūmi

\section{Abbreviations}

AKBh Abhidharmakośabhāṣya

BoBh Bodhisattvabhūmi

Bv Buddhavamsa

DBS Daśabhūmikasūtra

MB Mahābhārata

MP Milindapañha

MSA Mahāyānasūtrālaṃkāraśāstra

Karen O'Brien-Kop

karen.obrien-kop@roehampton.ac.uk

1 University of Roehampton, London, UK 


\begin{tabular}{|c|c|}
\hline PYŚ & Pātañjalayogaśāstra \\
\hline RV & $\operatorname{Rg}$ Veda \\
\hline Śbh & Śrāvakabhūmi \\
\hline SNS & Saṃdhinirmocanasūtra \\
\hline SPS & Saddharmapuṇụarīkasūtra \\
\hline Viv & Vivaraṇa \\
\hline YS & Yogasūtra \\
\hline YĀBh & Yogācārabhūmiśāstra \\
\hline YV & Yogaviṃśikā \\
\hline
\end{tabular}

The Pātañjalayogaśāstra ${ }^{1}$ (PYŚ) concludes with a description of the pinnacle of yoga practice: a state of samädhi called dharmamegha, cloud of dharma. Yet despite the structural importance of dharmamegha in the soteriology of Pātañjala yoga, the śästra itself does not say much about this term. Where we do find dharmamegha discussed at some length, however, is in Buddhist yogācāra, and more broadly in early Mahāyāna soteriology, where it represents the apex of attainment and the superlative statehood of a bodhisattva (one whose aim is to become a buddha). Given the relative paucity of Brahmanical mentions of dharmamegha in the early common era, Patañjali appears to adopt this key metaphor ${ }^{2}$ from a Mahāyāna context-and to revise its primary meaning from fullness to emptiness.

Within early Mahāyāna soteriology, the concept of dharmamegha is especially elaborated in yogācāra ${ }^{3}$ and particularly in various sections of Asanga's Yogācārabhümiśăstra. We have become accustomed to discussing just one yogaśāstra in the classical period, that of Patañjali, but, as I have argued elsewhere,

\footnotetext{
${ }^{1}$ Maas has argued that the Yogasūtra and its commentary the Yogasūtrabhăsya together comprise a single text under the title Pātañjalayogaśästra, compiled and composed by Patañjali around 325-425 CE (Maas 2006, 2010, 2013, pp. 57-68). Maas's framing of the text provides a useful working hypothesis in the current academic field within which we can evaluate the Yogasütra of Patañjali and its bhäsya. In this paper, I follow the convention of referring to the sūtra and bhāsya texts as one, the Pātañjalayogaśāstra, distinguishing sūtras in bold. I utilize Āgāse's critical edition (1904), supplemented by Maas (2006) for the first $p \bar{a} d a$. Any unattributed translations are my own.

${ }^{2}$ In this article, I discuss metaphor within the frame of conceptual metaphor theory. Conceptual metaphor theory (part of a broader approach of cognitive metaphor theory) was initiated by Lakoff and Johnson's Metaphors We Live By (Lakoff and Johnson 1980), which proposed two fresh ideas: firstly that metaphors are an inherent cognitive reflex and not a linguistic one and secondly that metaphors are not only analogous but also contingent. This theory was further developed in Lakoff (1987) and Lakoff and Turner (1989). Subsequent key scholars include Gibbs (e.g. Gibbs 2017) and Kövecses (e.g. Kövecses 2005, 2006, 2015). Cognitive metaphor theory has flourished in an interdisciplinary context in recent years and expanded to include definitions of metaphor as not only conceptual, but also linguistic, sociocultural, neural, and bodily (Kövecses 2006, p. 126).

${ }^{3}$ I follow other scholars, such as Deleanu (2006), in making a distinction between early yogācāras as Buddhist yoga adepts in the first centuries of the common era who were affiliated to Sarvāstivāda thought, and later Yogācāras who by the 5th-6th centuries had become established as a discrete philosophical school, or representatives of specific doctrinal positions, within Mahāyāna Buddhism. In a variant argument, Buescher suggests that the title Yogācāra should refer to the earliest strands of this school of thought and the compound Yogācāra-Vijñānavāda to a later, more developed strand (Buescher 2008, p. 2). As Gold notes: "There is strong reason to doubt that the term "Yogācāra" had its later, doxographic meaning—referring to a particular philosophical school—during Vasubandhu's time' (Gold 2015, p. 3).
} 
the Yogācārabhümiśāstra (YĀBh) is worth considering as another śāstra on yoga discipline from the same period. ${ }^{4}$ Since the earliest layers of the Yogācārabhūmiśāstra most likely predate the Pātañjalayogaśāstra, ${ }^{5}$ it is reasonable to suggest that there may have been conceptual influence from yogācāra to Pātañjala yoga. In this article, I lay out four possibilities that can account for the intertextuality and the stark contrast between the ways in which these two classical yogaśāstras-the Pātañjalayogaśāstra and the Yogācārabhūmiśāstra-employ the superlative ${ }^{6}$ metaphor of dharmamegha. Working from the premise that the Pātañjalayogaśāstra post-dates the early layers of the $\mathrm{YA} B \mathrm{Bh}$ and therefore reworks the Buddhist metaphor, I demonstrate that Patañjali's dharmamegha can be analysed as 1. a dead or commonplace metaphor, 2. a paralogical revision for polemical effect, 3 . logically concordant with Buddhist soteriology, or 4. a (by)product of literary style. I evaluate these four arguments in turn to suggest that Patañjali's strikingly empty metaphor of dharmamegha is largely a result of literary style and polemical revision due to doctrinal necessity.

\section{Patañjali's dharmamegha}

Scholars of classical yoga have long debated the meaning of the term dharmamegha in the Pātañjalayogaśästra, ${ }^{7}$ and the detail of the debate has been focused on what dharma means. ${ }^{8}$ One of the key reasons for the ongoing discussion is the polyvalence

\footnotetext{
${ }^{4}$ For the argument that we should consider the Yogācārabhümiśästra as a classical śāstra on yoga discipline, see O’Brien-Kop (2017, pp. 126-130, 2018, Chap. 3).

5 Maas's date range for the final redaction of the PYŚ is from 325-425 CE (see footnote 1). The dating of the Yogācārabhūmiśāstra is complex, but most scholars now settle on a final redaction in around the fourth century (Kragh 2013, p. 26). Yet the earliest two layers or 'books', the Śrāvakabhümi and the Bodhisattvabhümi, date to the 3rd century CE, if not before. As Demiéville first outlined, two Chinese meditation manuals were rendered from a lost Sanskrit work whose title has been reconstructed as the (hypothetically titled) *Yogācārabhūmi: the Xiuxing dao di jing (*Yogācārabhümi of Sañgharakșa) (T606; see Stuart 2015, 1: 15) and the Damoduoluo chan jing (The Meditation (Dhyāna) Scripture [Taught] by Dharmatrāta) (Demiéville 1951; Deleanu 2006, p. 157). This later text is also referred to as the Dharmatrāta Dhyānasūtra (DDS). The existence of these two texts (and others) demonstrates that there was already a textual tradition of Sarvāstivāda Buddhist meditation called yogācāra by the early 2nd century CE (if we go with Sangharakșa's dates) or by the late fourth to early fifth century (if we go with Buddhasena's dates). For further discussion of the datings of these yogācāra texts, see Demiéville (1951), Deleanu (2006), and Stuart (2015, p. 1).

6 In grammar, superlative is a term that indicates the highest degree of comparison between two or more objects. The comparative degree is applied in relation to two objects, whereas the superlative degree is applied to comparing more than two (Schertzer 1986, p. 37). 'Superlative' is also used in everyday expression to indicate the best of a series of possible states.

7 See, for example, Klostermeier (1986) and Rukmani (2007).

8 For a discussion of the 'dauntingly broad semantic range' of dharma in Indian religions, see Olivelle (1998, pp. xxxvii-xliii). In Brahmanism, dharma is the continuum of cosmic and social order derived from the content of Vedic injunctions and includes both an ontological and a normative dimension. In Buddhism dharma can mean universal law (both physical and moral), the body of Buddha's teaching (as one of the three 'jewels' or triratna of Buddha, dharma, samgha), and the constituent building blocks of reality. On the whole, most translators of the PYŚ have opted to interpret dharma as referring to an ontological category e.g. 'the Raincloud of [knowable] things' (Woods 1914, p. 341) or 'raincloud of essences' (Koelman 1970, p. 234). The other typical translation has been to render dharmamegha as
} 
of the term dharma. Moreover, Patañjali does not expound dharmamegha's meaning in any detail, and we do not often encounter this term in Brahmanical sources. It should be added that neither do the sub-commentators of the Pãtañjalayogaśāstra shed much light on dharmamegha as a technical term. In combination, these factors point to dharmamegha being an uncommon term in Brahmanism in the early common era. I suggest that we may approach the doctrinal denotation of this term in a more fruitful way by considering what megha (cloud) means; it is only by elucidating the metaphoric function of megha in dharmamegha that we can arrive at a better understanding of the meaning of dharma in this compound.

In the Pātañjalayogaśästra, there are two brief discussions of dharmamegha, which appear at the beginning and the end of the text. In itself, this positions these discussions as a structural and conceptual 'bracket' that frames the entire text. The first discussion takes place within the quintessential definition of yoga and the second discussion takes place in the concluding definition of liberation. In the first discussion, centred on dharmameghadhyāna, the meaning of dharma appears to be 'virtuous or religious conduct'. In the second discussion, centred on dharmameghasamādhi, the primary meaning of dharma is liberating knowledge. ${ }^{9}$

\section{Dharmameghadhyāna}

The first instance of dharmamegha occurs in the definition of dharmameghadhyanna (the absorption of dharmamegha). This appears in the bhāsya to the second sütra, the well-known yogaś cittavrttinirodhah (yoga is the cessation of mental fluctuation). The discussion explains how the mind must be sequentially purified of any vestige of the three gunas (tamas, rajas, and sattva). ${ }^{10}$

tad eva rajoleśamalāpetam svarūpapratiștham sattvapurușānyatākhyātimātram dharmameghadhyānopagam

bhavati. tat param prasamkhyānam ity ācakșate dhyāyinah

(PYŚ 1.2; Maas 2006, pp. 5-6).

When that very [sattva] is established in its own form, without the least measure of rajas, being merely the cognition of the distinction between sattva and purușa, it is conducive to dharmameghadhyāna. Those versed in dhyāna (dhyāyinah) call this [dharmameghadhyāna]

the highest enumerative reflection (prasamkhyāna).

\footnotetext{
Footnote 8 continued

'raincloud of virtue' (e.g. Mitra 1883, p. 203; Bangali 1976, p. 110; Rukmani 1981-1989, 4: 121). Less common is the translation of dharma to indicate teaching or body of knowledge, such as Skorupski's 'doctrine-cloud' (Skorupski 2009, p. 67).

9 While the ontological theory of dharma as 'building block of reality' is certainly present in the PYŚ, I argue that it does not inform the primary meaning of dharma in Patañjali's dharmamegha. For an example of dharma as ontological unit, see the commentary to PYŚ 4.33, which moves from a characterization of dharma as infinite knowledge into a related discussion of dharmins, properties. Dharmin is a key philosophical term to indicate the unchangeable property of a thing. See Maas (2014) for a full discussion of the transformation of dharma theory in the PYŚ from Buddhist sources.

10 The three gunas (qualities) are part of Sāṃkya ontology and are tamas (density), rajas (dynamism), and sattva (purity, balance).
} 
Table 1 PYŚ 1.2

\begin{tabular}{lll}
\hline tamas & rajas & sattva \\
\hline Lack of dharma & dharma & dharmamegha = prasamkhyāna \\
False knowledge & Knowledge & \\
Attachment & Detachment & \\
Weakness & Strength & \\
\hline
\end{tabular}

The passage describes the highest level of meditative attainment in which concentration is so restricted that it perceives just one thing: the difference between the sattva guna (the ontological state of pure balance) and purușa (the state of pure consciousness). Concentration can only access this stage by being devoid of any trace of rajas (tamas long since having been eliminated). This restricted perception of the 'difference' also represents the state of being established in one's own form, i. e. recognizing one's true nature as purușa. Additionally, the passage reveals that dharmameghadhyāna is also called prasamkhyāna (enumerative reflection) ${ }^{11}$ and confirms the enumerative aspect of prasamkhyāna in discerning discrete objects, in this case two objects (sattva from purusa). ${ }^{12}$ Dharmameghadhyāna, then, is a meditative technique that generates the capacity to discern the ultimate ontological distinction between prakrti (principle of materiality) and puruṣa (principle of pure consciousness).

In Patañjali's text there is no explanation of the term dharmamegha itself and what it means beyond its status as a label (of a technique or stage). However, in the preceding contrasting two descriptions of a citta (mind) that is pierced by either tamas or rajas, dharma is mentioned twice. In the case of tamas, the four characteristics of the mind are: lack of dharma, false knowledge, attachment, and weakness. ${ }^{13}$ In the case of rajas, the four characteristics are dharma, knowledge, detachment, and strength. ${ }^{14}$ These two paradigms mirror each other. I suggest that using dharmamegha to denote the presence of sattva represents a logical progression (beyond this mirroring) (Table 1).

Notably, dharma is the only one of the four characteristics carried forward into the description of a mind with sattva. In such a framework, dharma continues the semantic denotation of the prior two sentences and means 'religious conduct' or 'virtuous behaviour'. 15 In this context, the connection to the cloud image indicates an exceptionally elevated, i.e. ideal, state of dharma. With regard to dharma, then,

\footnotetext{
11 For a discussion of this translation of prasamkhyāna, see O'Brien-Kop (2017).

12 Sattva here represents the subtlest and purest aspect of one's own mind, which must also be abandoned when one realises that it belongs to prakrti (the principle of materiality).

13 tat tamasānuviddham, adharmājñānāvairāgyānaiśvaryopagam bhavati (PYŚ 1.2; Maas 2006, pp. 4-5).

14 tad eva prakṣinnamohāvaraṇam sarvatah pradyotamānam, rajomātrayānuviddham, dharmajñānavairāgyaiśvaryopagam bhavati (PYŚ 1.2; Maas 2006, p. 5).

15 With regard to the individual mind, dharma most appropriately refers to virtuous attitude or religious conduct and not to dharma as 'ontological unit' or 'body of teachings', the other two most common meanings for dharma. The inclusion of dharma in a list of other human and mental qualities (e.g. knowledge, detachment, strength) further reinforces that this is how we should read it in this context.
} 
citta has three expressions, which match the three gunas: lack of dharma (tamas), presence of dharma (rajas), and exceptional dharma (cloud of dharma) that surpasses convention (sattva).

\section{Dharmameghasamādhi}

Patañjali's second reference to dharmamegha occurs at the end of the śāstra, where it is discussed in more detail. ${ }^{16}$ This description is of the highest attainment of yogic concentration, or dharmameghasamädhi (the concentration of the cloud of dharma). Here, we learn that dharmameghasamädhi is equivalent to the samädhi that is without seed of samskāra (mental imprint):

\section{prasamkhyāne 'py akusīdasya sarvathā vivekakhyāter dharmameghah samādhih ॥}

yadāyạ̣ brāhmaṇah prasaṃkhyāne 'py akusīdas tato 'pi na kiṃcit prārthayate. tatrāpi viraktasya sarvathā vivekakhyātir eva bhavatīti saṃskārabījakșayān nāsya pratyayāntarāṇy utpadyante. tadāsya dharmamegho nāma samādhir bhavati (PYŚ 4.29; Āgāse 1904, p. 202)

For one who is without investment even in enumerative reflection (prasamkhyāna), dharmameghasamādhi arises from complete discriminating discernment (vivekakhyāti).

When this Brahmin is without investment even in enumerative reflection, then he does not strive whatsoever. Therefore one who is completely devoid of attachment thereto [to prasamkhyāna] has only discriminating discernment. Because of the destruction of the seed of samskāra, no other ideations arise. Then, there arises the samādhi that is called dharmamegha.

We previously encountered the state of seedless concentration; nirbīja samādhi was explained at PYŚ 1.51. Hence, the equivalence in the above passage would appear to confirm that dharmameghasamādhi and nirbïja samādhi are synonyms. As I have noted, the opening of the PYŚ presents dharmameghadhyāna as equivalent to prasamkhyāna (enumerative reflection). Now, it is explained that only when one abandons this technique of prasamkhyāna (the act of perceiving the difference between sattva and purușa, i.e. dharmameghadhyāna), can one attain the ultimate state of dharmameghasamädhi. We have, then, a simple progression that can be expressed in two ways: to say that prasamkhyāna leads to nirbïja samādhi is equivalent to saying that dharmameghadhyāna leads to dharmameghasamādhi. ${ }^{17}$ The state of dharmameghasamädhi is further characterized as a state of infinite knowledge:

tadā sarvāvaranamalāpetasya jūānasyānantyāj jũeyam alpam ॥ (PYŚ 4.31; Āgāśe 1904, p. 203).

Then for one who is free from the impurity of all obscuration due to infinite knowledge, that which is to be known is little.

\footnotetext{
16 PYŚ 4.29; 4.31-32.

17 The progression of dharmamegha from a state of dhyāna to one of samādhi represents the typical sequence from absorption to concentration, such as we see in both Pātañjala and Buddhist schemes of meditation.
} 
This description of the cloud of dharma as infinite knowledge supports the reading of dharma in this instance as 'body of teaching/doctrine'. Additionally, dharmameghasamädhi is also a state in which change and transformation are brought to a halt (PYŚ 4.32). ${ }^{18}$ If, as we are told in PYŚ 1.1, yoga is samādhi, then the superlative state of yoga is dharmameghasamädhi. This is a liberated state of cessation.

From these two accounts of dharmamegha in the Pātañjalayogaśāstra, we can assert that dharmamegha can be both ethical-ontological (the virtuous condition of sattvaguna) and epistemological (the condition of unlimited knowledge) and that dharmameghasamādhi is a superlative state of cessation.

\section{Dharmamegha in Buddhist Sources}

In contrast to the dearth of sources for the term dharmamegha in Brahmanical texts, ${ }^{19}$ there is an abundance of references in Buddhist literature. In Buddhism, the abstract concept of dharma is frequently represented via metaphors. For example, in the late-canonical Buddhavamsa (1st-2nd century BCE) we are told how the future Buddha will enlighten all beings. This is explained with three metaphors: the Dhamma-ship, the Dhamma-mirror, and the Dhamma-medicine (Collins 2010, p. 183). Each of these metaphors contains dense clusters of association, e.g. the ship as a vehicle for safe passage, the mirror as reflecting self-knowledge and awareness, and medicine as a healing modality. Dharmamegha is perhaps just one of the myriad metaphors in Buddhism that attempt to scaffold the meaning of terms like dharma. Nonetheless, whatever its origins, dharmamegha was picked up and amplified in a certain strand of Mahāyāna literature.

\footnotetext{
${ }^{18}$ tatah krtāirthānām pariṇāmakramasamāptir guṇānām $\|$ tasya dharmameghasyodayāt kṛtārthānām guṇānām parịnāmakramaḥ parisamāpyate / na hi krtabhogāpavargāḥ parisamāptakramāh kṣaṇam apy avasthātum utsahante (PYŚ 4.32; Āgāse 1904, p. 204). 'Then the gunas have accomplished their purpose when the sequence of transformation is fully completed. Due to the emergence of the cloud of dharma, the gunas have accomplished their purpose and the sequence of change is fully completed, for [when] experience and emancipation are done, the sequences complete, they [the gunas] cannot bear to continue for even a moment.'

19 Although cloud images are common in the Mahābhärata, the term dharmamegha does not appear, and the contexts of the cloud metaphor can be general and varied. The verses MB 12.304.18-27 explain the characteristics of the yoga adept in terms of similes. The first two are familiar because we encounter them in the PYŚ, the lamp and the cloud: nivāte tu yathā dīpo jvalet snehasamanvitah / niścalordhvaśikhas tadvad yuktam āhur manīṣinah / pāṣāna iva meghotthair yathā bindubhir āhatah / nālam cālayitum śakyas tathā yuktasya lakșanam (MB 12.304.19-20; Belvalkar 1954, Vol 15: 1680). 'But as a lamp in a windless place, filled with oil, will burn with the motionless up-rising flame, in the same way, the wise describe the disciplined (Yoga-adept). As a stone, struck by water-drops coming from a cloud, cannot be disturbed, such is the mark of the disciplined (Yoga-adept)' (trs. Edgerton 1965, p. 327). This raincloud image is not one of dharmamegha, but rather serves a different function to illustrate the non-responsive nature of a stone-like yogin.
} 


\title{
Dhammamegha in Pāli Sources
}

Some of the earliest detailed discussions of dhammamegha in the Pāli canon are to be found in the Apadāna and the Buddhavamsa, both containing biographical stories about the Buddha. ${ }^{20}$ For example, the Apadanna ${ }^{21}$ states:

\author{
dhammameghena vassante sabbe hontu anāsavā \\ ye'ttha pacchimakā sattā sotāpannā bhavantu te \\ (Apadāna, Buddhāpadānam 68; Lilley 1925-1927, Part 1: 5) \\ While the dharmamegha rains, may all contaminations cease; may [people] \\ live according to their perfections, may they become stream-enterers.
}

In the Buddhavamsa, the Buddha is described both as being the agency of dhammamegha and as having a causative relationship to dhammamegha. As the agency of the cloud, the Buddha rains the showers of dharma:

so pi patvāna sambodhim santārento sadevakam

abhivassi dhammameghena nibbāpento sadevakam

(Bv 17.2; Jayawickrama 1974, p. 68)

\footnotetext{
20 This is according to the Päli Tipitakam Concordance (Woodward et al. 1973, Vol 2: 413). These texts both occur in the Khuddaka Nikāya, the fifth and last division of the Sutta Pitaka.

21 The Apadāna also contains an interesting discussion of dhammamegha in relation to procreative fertility: Yathāpi padumam nāma sūraramsena pupphati / tath'; evāham mahāvīra buddharamsena pupphito. // Yathā balākayonimhi na vijjati pumā sad̄̄ / meghesu gajjamānesu gabbham gaṇhanti tā sadā. // Ciram pi gabbham dhārenti yāva megho na gajjati / bhārato parimuccanti yadā megho pavassati. // Padumuttarabuddhassa dhammameghena gajjato / saddena dhammameghassa dhammagabbham agaṇhi'ham. I/ Satasahassạ̣ upādāya puñ̃̃agabbham dharem ahạ̣ / nappamuccāmi bhārato dhammamegho na gajjati. I/ Yadā tuvam Sakyamuni ramme Kapilavatthave / gajjasi dhammameghena bhārato parimucc' aham. // Suñ̃atam animittañ ca tathāpaṇihitam pi ca / caturo ca phale sabbe dhamme 'va vijațāy' aham. // (Apadāna, Therāpadāna 1.6.70-76; Lilley 1925-1927, Part 1: 42) 'And just as a lotus flower blooms due to the rays of the sun, so too do I, O Great Hero, bloom because of the Buddha-rays. Just as male birds are not always found mating with the female cranes [but only] when the clouds do rumble do they take them to their wombs, and for much time they stay pregnant-as long as the clouds don't thunder - then they are freed from that burden when the clouds are raining [again], [so] when the Dhamma-cloud thundered of Padumuttara Buddha, due to that Dhamma-cloud's loud sound I [then] conceived a Dhamma-womb. Serving for a hundred thousand [aeons] I bore that merit-fetus. I was not freed from that burden; the Dhamma-cloud did not thunder. But when you, Sage of the Sākyas did thunder from your Dhamma-cloud in lovely Kapilavastu, I was set free from that burden. [Then] I explained the whole Teaching and also its four fruits, which are: emptiness, the absence of marks, suchness, intentionality' (trs. Walters 2017, pp. 87-88). The association between dhammamegha and Padumuttara, the 10th of the 28 Buddhas (Malalasekera 1938, II: 136), is reinforced in Chapter Four: Vāsavam viya vassantam dhammamegham anāsavam / sāradādiccasadisam ramịijālākulañ jinam (Apadāna, Therī-Apadāna 2.17.98; Lilley 1925-1927, Part 2: 537). 'The Victor, like autumnal son, surrounded by garlands of rays, without constraints, that Dhamma-cloud rained forth like the king of the gods' (trs. Walters 2017, p. 1034). There is one further discussion of dhammamegha, again in relation to Padumuttara: Guṇānam āyati bhūto ratanānam va sāgaro / pajjunno pi va bhūtāni dhammameghena vassati (Apadāna, Therāpadāna 54.530.4; Lilley 1925-1927, Part 2: 468), 'Like the ocean for gems, he is the future for the virtuous; like a rain-cloud for living things, he rains by the cloud of Teaching' (trs. Walters 2017, p. 887). Since both Padumuttara and Paduma (the eighth of the twenty-four Buddhas; Malalasekera 1938, II: 131) are described as engendering a shower of lotuses, it is not clear why they should be directly connected with the rain of dhammamegha, other than symbolically.
} 
After he had attained Self-Awakening and was causing the world with the devas to cross over, he rained down from the cloud of Dhamma making the world with the devas cool (trs. Horner 1975, p. 67).

In contrast, the Buddha's causative relation to the rain of dharma is outlined here:

dhammameghạ̣ pavassetvā temayitvā sadevake

khemantạn pāpayitvāna nibbuto so sasāvako

(Bv 21.26; Jayawickrama 1974, p. 81)

Having made the cloud of Dhamma rain down moistening the world with the devas (Bv 21.26; trs. Horner 1975, p. 80) [author's italics].

Beyond the Pāli canon, dhammamegha appears in relation to yoga in the 1st-2nd century CE Milindapañha, in which the Indo-Greek king Menander poses questions about Buddhism. The example of dhammamegha appears in a long list of similes self-consciously presented to construct the paradigms of right behaviour for the earnest yogin. Using the structure of simile, the text lists five qualities of the cloud (megha) that the yogin yogâvacara is said to possess. The cloud is also understood to be a raincloud, and the five qualities of rain-settling, cooling, nurturing, protective, and abundant-are mapped to the yogin. The passage explains that dharmamegha is a fruit of yogācāra (Pāli: yogāvacara), or yoga discipline, and its function is to provide sustenance and nourishment to the world.

'Revered Nāgasena, when you say five qualities of the rain-cloud must be adopted, which are these five qualities that must be adopted?'

'As, sire, the rain-cloud allays dust and dirt that are arising, even so, sire, the yogin, the earnest student of yoga must allay the dust and dirt of the defilements that are arising. This, sire, is the first quality of the rain-cloud that must be adopted.

And again, sire, the rain-cloud cools the heat of the earth; even so, sire, the yogin, the earnest student of yoga must cool the world with the devas by the meditation of loving-kindness. This, sire, is the second quality of the raincloud that must be adopted.

And again, sire, the rain-cloud makes all seeds grow; even so, sire, the yogin, the earnest student of yoga, having in all creatures generated faith, should sow the seed of faith for (achieving) the three attainments: the deva-like and the human attainments and the attainment of the bliss of nibbāna, the ultimate goal. This, sire, is the third quality of the rain-cloud that must be adopted.

And again, sire, a rain-cloud, arising in due season, preserves the base of the dharan̄inuha (tree), the grasses, trees, creepers, bushes, medicinal plants and forest-trees; even so, sire, the yogin, the earnest student of yoga, having produced careful attention must, by means of that careful attention, preserve the Dhamma of recluses, so that all skilled states are rooted in careful attention. This, sire, is the fourth quality of the rain-cloud that must be adopted.

And again, sire, the rain-cloud in raining down fills rivers, reservoirs, lotusponds and gullies, crevices, lakes, water-pools and wells with showers of water; even so, sire, the yogin, the earnest student of yoga, having rained down 
the rain-cloud of Dhamma for the mastery of the tradition, should perfect the mind (of others) for the spiritual realisations they are longing for. This, sire, is the fifth quality of the rain-cloud that must be adopted. And this, sire, was said by the Elder Sāriputta, the General under Dhamma:

\author{
"'Seeing folk capable of being awakened \\ Even be they a hundred or a thousand yojanas (distant), \\ Approaching them at the right moment \\ The Great Sage awakens them", \\ (MP 7.56; trs. Horner 1963-1964, Vol 2: 291-292). ${ }^{22}$
}

In comparison to the previous canonical examples, dhammamegha here is associated not with the Buddha, but with the agency of 'the earnest yogin' who takes centre-stage in book seven of the Milindapañha. ${ }^{23}$ The rich detail provided by this simile is worth noting because in a simile the process of domain-mapping (transferring qualities) from source to $\operatorname{target}^{24}$ is more evident than in a metaphor,

\begin{abstract}
${ }^{22}$ Yathā, mahārāja, megho uppannam rajojallam vūpasameti, evameva kho, mahārāja yoginā yogāvacarena uppannam kilesarajojallạn vūpasametabbaṃ. Idam, mahārāja, meghassa paṭamam an்gạ̣ gahetabbaṃ. Puna ca parạ̣, mahārāja, megho pathaviyā uṇhạ̣ nibbāpeti, evam eva kho, mahārāja yoginā yogāvacarena mettābhāvanāya sadevako loko nibbāpetabbo. Idam, mahārāja, meghassa dutiyam àngam gahetabbam. Puna ca param, mahārāja megho sabbabījāni virūhāpeti evam eva kho mahārāja yoginā yogāvacarena sabbasattānam saddham uppādetvā tạ̣ saddhābījam tīsu sampattisu ropetabbaṃ, dibbamānusikāsu sampattisu yāva paramatthanibbānasukhasampatti. Idam maharaja meghassa tatiyam an்gam gahetabbam. Puna ca param maharaja megho ututo samuțthahitvā dharanitalaruhe tinarukkhalatāgumbaosadhivanappatayo parirakkhati evam eva kho maharaja yoginā yogāvacarena yoniso manasikāram nibbattetvā tena yoniso manasikārena samanadhammo parirakkhitabbo, yoniso manasikāramūlakā sabbe kusalā dhammā. Idam mahārāja meghassa catuttham añgạ̣ gahetabbạ̣. Puna ca parạ̣ mahārāja megho vassamāno nad̄̄ talākapokkharaniyo kandarapadarasarasobbhaudapānāni ca paripūreti udakadhārāhi evam eva kho mahārāja yoginā yogāvacarena āgamapariyattiyā dhammameghamabhivassayitvā adhigamakāmānam mānasam paripūrayitabbam (MP; Trenckner 1962, pp. 410-411).
\end{abstract}

23 Klostermeier also translated this passage in a key article that highlighted Buddhist textual sources for the image of the cloud within the context of yogalyogācāra: '1. As the rain-cloud settles the dust on the road, so the yogin, by means of his yoga practice, should settle the dust of afflictions (kilesarajojallam). 2. As the rain-cloud allays the heat of summer, so the yogin, through his practice of friendliness (mettābhāva), should reduce the heat of the whole world (nibbāpetabo). 3. As the rain-cloud makes all kinds of plants grow, so the yogin should make faith (saddhā) arise and grow. 4. As the rain-cloud affords protection in the hot season to vegetation, so the yogin, by virtue of mindfulness (manasikära), should protect the samanadhamma. 5. As the rain-cloud, when it opens up, fills brooks and streams and wells and lakes, so the yogin, by virtue of his yoga life (yogāvacarena) well-grounded in the scriptures $(\bar{a}$ gamapariyattiy $\bar{a})$, should open the 'raincloud of dharma' (dharmamegha) and make it pour down fulfillment to the minds of those who are desirous of learning' (trs. Klostermeier 1986, pp. 257-258). However, in his translation of the term dharma, Klostermeier comes down on the side of dharma as ontological factor. Making an anachronistic leap, he translates megha as 'field' in the sense of modern physics': 'Dharmamegha samādhi would then be a condition in which the dharmas, which on a lower level of consciousness have been perceived as differentiated into a great number of specific dharmas, now are perceived in their (unified) dharma-character' (Klostermeier 1986, p. 260). However, in turning megha (cloud) into a spatial 'field' to make it match an ontological interpretation of dharma, Klostermeier does the term an injustice and overlooks its metaphoric importance for Patañjali. Wujastyk (2018) also discusses Klostermaier's work.

24 Lakoff and Johnson introduced the idea that metaphor is produced by 'domain-mapping'. This is the cognitive process by which one area of life (a domain) is conceptualized in the terms of another, with the properties transferred from one domain to the other (Lakoff and Johnson 1980). Thus two unconnected 
which is a more compressed linguistic and cognitive form. When we review the literary use of this metaphor further along, we must consider that the qualities so explicitly outlined in this simile are not always so explicit in a metaphor. ${ }^{25}$

\section{Saddharmapuṇ̣̂rīkasūtra and Daśabhūmikasūtra}

Despite the early context for dhammamegha in Pāli sources, the most well-known discussions of dharmamegha in Buddhist literature are in the early Mahāyāna sūtras, particularly the Saddharmapundarīkasūtra and the Daśabhūmikasūtra, both dated to the early centuries CE.

The Saddharmapundarīkasūtra (SPS) is often identified as the first sūtra text of the Mahāyāna corpus, proclaiming, as it does, the new vehicle. The text was produced in phases from circa 1 st century BCE to 3rd century $\mathrm{CE}$, and among the earliests layers of the Saddharmapundarikasütra are the verse sections in Chapter Five. ${ }^{26}$ Chapter Five, which deals with medicinal herbs ('Oșadhi-parivarto nāma pañcamaḥ'), contains extraordinarily detailed descriptions of the rain of true dharma. Although the compound dharmamegha does not itself appear in this chapter, this sütra offers the first extended association of the Buddha with a raincloud of dharma.

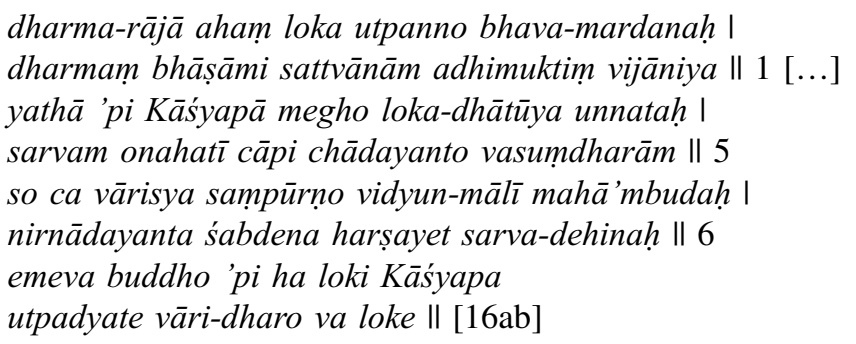

(SPS 5.vv1, 5-6, 16; Wogihara and Tsuchida 1934, pp. 117-118).

The King of Dharma I am, who arose in the world to crush becoming;

Dharma I teach to beings, after I have discerned their dispositions.

It is like a great cloud which rises above the earth,

Footnote 24 continued

spheres of life are drawn together. People construct concepts, particularly abstract ones, by mapping their knowledge of more concrete domains to more abstract domains. The process of connecting two domains in metaphor can be partially accounted for by similarity. Using the stock example of 'Achilles is a lion', the two domains are: 'the specific man called Achilles' and 'a lion'. In the domain-mapping, the qualities of the source domain (the lion) are 'transferred' or 'mapped' to the target domain (Achilles), so that, although it is not explicitly stated, Achilles is understood in the terms of a lion: a hunter, powerful, fierce, a wild creature, with a mane, deadly, etc. However, domains are frequently connected by convention rather than inherent likeness. One example of this is mapping attributes from the domain of agricultural cultivation to the more abstract domain of 'spiritual cultivation'-there is little analogical basis for connecting these two domains.

25 It is also important to note that passages similar to this appear elsewhere in the Pāli canon, although not with reference to dhammamegha (e.g. Samyutta Nikāya ii 32).

26 The fifth chapter contains both prose and verse sections, both of which describe the cloud of dharma. One point to note is that the verse sections are the earliest layers of the text, dated to the beginning of the first millennium and therefore predating Patañjali's sūtrabhāṣya. 
Which covers up everything and overshadows the firmament, And this great cloud, filled with water, wreathed with lightning, Resounds with thunder, and refreshes all the creatures.

Just so, O Kasyapa, the Buddha also

Arises in this world just like a rain-cloud (trs. Conze 1954, pp. 139-140).

The emphasis and repetition of the association between the Buddha and the raincloud over the course of this chapter is a new statement of doctrine. But it is not yet formulaic or standardised; in these verses the most frequent word used for cloud is megha, also giving rise to mahāmegha or 'great cloud'. However, other terms for (rain)cloud are also used: mahā'mbudah (Wogihara and Tsuchida 1934, p. 117, v6a), vāridhara (Wogihara and Tsuchida 1934, p. 118, v16b), and varșam (Wogihara and Tsuchida 1934, p. 120, v26d and 121, v36a). Interestingly, when varșam appears, it is in the compound dharmavarșam, and so the closest we get to dharmamegha in the Saddharmapuṇdarīkasūtra is dharmavarșam. (I will return to this point below).

One of the central features of this rain of dharma is that it nourishes all life equally:

saṃtarpayāmī imu sarva-lokam

megho va vārim sama muñcamānah I

(SPS 5.v24; Wogihara and Tsuchida 1934, p. 118)

I refresh this entire world

Like a cloud which releases its rain evenly for all

(trs. Conze 1954, p. 140).

This assertion is fundamental to the new Mahāyāna doctrine of the Saddharmapundarīkasūtra. The text has to justify why the true teaching (or the new vehicle) has only been revealed now and not previously-and, in order to do so, the text locates agency on the part of the disciples and not on the part of the Buddha himself. The argument proceeds thus: even though rain falls equally on seeds, some seeds turn into flowers and some into trees-it depends upon the capacity of the seed itself.

mamāpi co varșatu dharma-varșam loko hy ayam tarpitu bhoti sarvah I yathā-balam cānuvicintayanti subhāṣitạ̣ eka-rasam pi dharmam ॥ tṛna-gulmakā vā yatha varșamāne madhyā pi vā oṣadhiyo yathaiva I drumā pi vā ta ca mahā-drumā vā yatha śobhayante daśa-dikṣu sarve ॥ iyam sadā loka-hitāya dharmatā tarpeti dharmen’ imu sarva-lokam I samtarpitaś cāpy atha sarva-lokah pramuñcate oṣadhi puṣpakāṇi ॥ (SPS 5.vv36-38; Wogihara and Tsuchida 1934, p. 121)

When I rain down the rain of the Dharma, 
Then all this world is well refreshed.

Each one according to their power takes to heart

This well-preached Dharma, one in taste.

As when it rains the shrubs and grasses,

The bushes and the smaller plants,

The trees and also the great woods

Are all made splendid in the ten regions;

So the nature of Dharma always exists for the weal of the world,

And it refreshes by this Dharma the entire world.

And then, refreshed, just like the plants,

The world will burst forth into blossoms (trs. Conze 1954, p. 140).

This indicates that the true dharma has been available all along, but that a lack in the capacity of the disciples resulted in the lack of yield. The image of this 'just rain of dharma' provided by the Buddha is central to the text's strategies of validation for its new doctrine.

The other key source in early Mahāyāna for the raincloud of dharma metaphor is the Daśabhümikasūtra (DBS). ${ }^{27}$ Although not explicitly a text about yoga, the Daśabhümikasütra employs the discourse of yoga. This text describes the ten stages or bhümis ${ }^{28}$ of attainment in the bodhisattva path to liberation, and the tenth stage, the bodhisattvabhümi, is also called dharmameghabhümi (the stage of the cloud of dharma). At the second level of the daśabhümis, we are told about the aim of yoga:

tata uttarataram pariśodhitāh sarvākārapariśodhitatvād yāvad daśabalabalatvāya sarvabuddhadharmasamudāgamāya samvartante tasmāt tarhy asmābhị samābhinirhāre sarvākārapariśodhanābhinirhāra eva yogah karaṇīyah

(DBS 2P; Rahder 1926, p. 26).

They [the adepts] are even more highly purified than that as a result of being purified of all forms when they approach full knowledge of every buddhadharma, the power of the ten balas. As a result of that, then, it is only when total realization (samābhinirhāra), ${ }^{29}$ happens, i.e. realization of the purification of all forms, that we should practise yoga.

Unlike in the Pātañjalayogaśāstra, we do not find discussions of dharmameghadhyāna or dharmameghasamādhi, but rather dharmameghabhūmi.

\footnotetext{
27 Although the Daśabhümikasūtra was initially an independent text, it was later absorbed into a large compilation, the Avatamsakasütra (early centuries CE). It was first translated into Chinese by Dharmarakșa in the $3^{\text {rd }}$ century CE (Schmithausen 2016, p. 401). Although the ten stages (daśabhūmi) are also represented in other Mahāyāna texts such as the Lankkāvatārasūtra (which also discusses dharmamegha) and the Śñrangamasütra, this present article focuses on the more obvious line of transmission from the Daśabhümikasūtra to the Yogācārabhūmiśáśtra, discussed further along and in footnote 31 .

28 The ten bhūmis are: pramuditā, vimalā, prabhākarī, arciṣmati, sudurjayā, abhimukhī, dūraṃamā, acalā, sādhumatī, dharmameghā. For an elucidation of the ten stages, see Bagchi (1967, pp. 1-23).

29 According to Edgerton's Buddhist-Hybrid Sanskrit Dictionary, abhinirhāra means accomplishment, production or realization, often in relation to the mind, self, vows, etc. (Edgerton 1953). I have been unable to discern the technical meaning of the prefix sama- in relation to abhinirhāra and suggest 'total'. For a brief discussion of abhinirhāra, see Deleanu (2006, 2: 477 fn31).
} 
Dharmamegha represents the 10th perfection (päramitā), which is perfection of knowledge (jĩ̄anapāramitā). This bhümi, the tenth stage in the bodhisattva path, ${ }^{30}$ is also called the abhișekabhümi, the level of anointment or coronation. The bodhisattva is like an ocean that can soak up the infinite amount of knowledge that rains down like a deluge from a raincloud.

tadyathāpi nāma bho jinaputrāḥ sāgaraṇāgarājameghavișșțo mahān apskandho na sukaro 'nyena prthivipradeśena soḍhum vā sampratyeșitum vā svīkartum vā samdhārayitum vā anyatra mahāsamudrāt / evam eva bho jinaputrā ye te tathāgatānām bhagavatām guhyānupraveśā yad uta mahādharmāvabhāsā mahādharmālokā mahādharmameghās te na sukarāh sarvasatvaih sarvaśrāvakapratyekabuddhaih prathamām bhūmim upādāya yāvan navamībhūmipratișthitair api bodhisatvais tān bodhisatvo 'syām dharmameghāyām bodhisatvabhūmau sthitah sarvān sahate sampratīcchati svīkaroti samihārayati (DBS 10H; Rahder 1926, p. 89)

Oh you jinaputras, just as a great mass of water that is poured from a cloud of the ocean serpent-king is not easily borne, desired, claimed and drawn in by any other region of earth than the great ocean, thus, oh jinaputras, those who are entered in the secret of the divine buddhas - which is the revelation of the great dharma, the light of the great dharma, the cloud of the great dharma this is not easily done by all beings, by all who are srāvaka and pratyekabuddha, or even by all bodhisattvas established in the first stage up to the ninth stage. It is the bodhisattvas established in this bodhisattva stage called dharmamegha who bear, desire, get and possess all of it.

In the Daśabhümikasūtra, then, dharmameghabhümi is the pinnacle of the path of practice for a bodhisattva. It represents innumerable samädhis, infinite knowledge, and abundant growth.

\section{Dharmameghabhūmi in the Yogācārabhūmiśāstra}

The term dharmamegha is also discussed in two sections of the Yogācārabhūmiśāstra: in the Bodhisattvabhümi (BoBh) and in the Samdhinirmocanasütra (SNS). I will discuss the Bodhisattvabhümi here, and the Samdhinirmocanasūtra in a section further along. The Bodhisattvabhūmi draws on the Daśabhūmikasūtra for its tenfold scheme. ${ }^{31}$ At dharmameghabhümi, the bodhisattva becomes omniscient like a cloud

\footnotetext{
${ }^{30}$ Elsewhere, in the Ratnameghasūtra it is suggested that a bodhisattva may need to be a yogācāra, practitioner of yoga discipline. The Ratnameghasütra contains information on how a bodhisattva should practice ascetic activity. Silk translates this passage from the Tibetan: 'if people are endowed with ten qualities they are noble bodhisattvas [...] [if they] are yogācāras who abundantly contemplate emptiness' (Silk 2000, p. 297). Schopen notes that although this text was only translated into Chinese in the 6th century CE, it 'is quoted three times in the Sūtrasamuccaya which might be by Nāgārjuna' around the 2nd century (Schopen 2006, p. 346).

31 The Bodhisattvabhūmi states this explicitly in the Daśabhümikasūtra: vistaranirdeśatah punar yathāsūtram eva daśabhūmike pramuditabhūminirdeśam ārabhya. yāś ca daśabhūmike sūtre daśa bodhisattvabhümayah (BoBh; Wogihara 1930-1936, p. 332, line 21). 'Moreover, the elaborated teaching according to the sūtra is in the Daśabhümika, commencing with the instruction on the stage of joy. And those ten [stages] in the Daśabhümika Sütra are those of the Bodhisattvabhümi.'
} 
that produces rain to provide sustenance to the world.

paripūrṇabodhisattvamārgaḥ suparipūrṇa-bodhisambhāraś ca sa bodhisattvah tathāgatānām amtikād dharmameghabhūtām atyudārām duhsahām tadanyaih sarvasattvais saddharmavrșțim sampratīcchati / mahāmeghabhūtaś ca svayam anabhisambuddhabodhir abhisambuddhabodhiś ca aprameyānām sattvānām saddharma-vrștyā nirupamayā kleśarajāmsi praśamayati / vicitrāṇi ca kuśalamūlaśasyāni virohayati vivardhayati pācayati tasyām bhūmāv avasthitah / tasmāt sā bhūmir dharmameghety ucyate / tenaiva cārthena paramo vihāro draștavyah (BoBh 2.4.12; Wogihara 1930-1936, pp. 354-355) The bodhisattva who has completed the bodhisattva path and fulfilled all requisites for awakening, [being] near the tathāgatas, immediately desires a rain of true dharma, grand and unbearable for all beings other than him, being the cloud of dharma. That [bodhisattva] consists of a great cloud [that] automatically [contains both] the awakening by non-enlightenment and the awakening by enlightenment and causes to be settled the particles of dust of the kleśas of countless beings by means of an incomparable rain of true dharma. While established in this stage [ground], he causes the diverse virtuous roots of grain [corn] to sprout, grow and mature. This is the reason why this stage is called dharmamegha. And it is only by means of this that the supreme abode is experienced.

The bodhisattva enters into deeper meditation, acquiring endless samādhis and limitless powers, and overcomes even the subtlest trace of the kleśas (mental afflictions). The cloud has a beneficial function in that it produces growth, proliferation and propagation of virtue. ${ }^{32}$

In structure, the Bodhisattvabhümi is similar to another text that is generally attributed to Asanga, the Mahāyānasūtrālamikāraśāstra (MSA). ${ }^{33}$ This treatise, which provides an overview of the yogācāra frame and the path of the bodhisattva, also refers to dharmamegha, both in the verses themselves and in the commentary (which may have been authored by Vasubandhu). In the commentary to Mahāyānasūtrālamikāraśāstra 11.46, dharmamegha denotes mastery over action attained by the bodhisattva. ${ }^{34}$ In Chapter 20, one of two chapters outlining signs of practice and attainment, dharmamegha is the tenth stage of the bodhisattva's progress and has a technical meaning of 'pervasion' 'because it is like a raincloud in the sky of the Dharma, pervading both (concentrations and retentions)' (MSA 20.38cd; trs. Jamspal et al. 2004, p. 332). ${ }^{35}$ The commentary to this verse adds: " "pervading both" means that because the Dharma-permeating the foundational

\footnotetext{
32 Dharmamegha also appears as one part of a threefold cluster called mahädharma which enfolds mahādharmamegha along with two other dharma complexes: mahādharmāvabhāsā, (the revelation of the great dharma), mahādharmālokā, (the light of the great dharma) and mahādharmamegha (the cloud of the great dharma).

33 For a summary of the complex debates on whether Asanga or Maitreya(-nātha) authored the verses in this text, as well as the theories of composition of the commentary, see Sakuma (2013, esp 335-336 fn11, 12).

34 dharmameghāyām karmānyabhijñakarmaṇāmavyāghātāt (Lévi 1907, p. 66).

35 dharmameghā dvayavyāpter dharmākāśasya meghavat (Lévi 1907, p. 183).
} 
(consciousness), and attained by means of the doors of concentrations and retentions —is like a raincloud (pervading) the sky-like (Dharma-realm)' (trs. Jamspal et al. 2004, p. 332). ${ }^{36}$

\section{Vedic Forerunners of the Cloud of Dharma}

Despite the proliferation of dharmamegha in Buddhist sources, the vibrant elemental imagery of the raincloud is not, of course, unique to the Buddhist conceptual sphere. In Vedic ritual, rainfall is one of the frequently cited objectives of the fire sacrifice. Furthermore, the fire of tapas produces power in the ascetic, 'which may manifest itself as a sexual and fecundating energy which when released generates rainfall, fertile fields, and biological offspring' (Kaelber 1989, p. 144). ${ }^{37}$ The Vedic deities such as Soma, Agni, Varuna and Indra were all closely associated with water. As Proferes states: 'these gods reside in water, generate rain, or set the cosmic stream free to flow to earth for the benefit of humankind' (Proferes 2007, p. 78). In its description of the anointing or abhiseka of the king, the Rg Veda carries the image of the unction waters as a raincloud (abhravarșa, lit. 'cloud-rain') of soma pouring down on earth, streaming with light and splendour.

ete somā ati vārāṇy avyā

divyā na kośāso abhravarșāh,

vrthā samudram sindhavo na nīcīh

sutāso abhi kalaśām asrgran (RV 9.88.6)

These pressed soma juices, like heavenly buckets of cloud-rain, streamed at will through the heavenly wool strainer into the vessels like rivers downwards to the sea (cited and trs. Proferes 2007, p. 94).

Water forms a central part of the rituals of abhiseka, consecration in the form of the sprinkling of liquids and water (Davidson 2002, p. 123; Proferes 2007). ${ }^{38}$ Indeed, as Proferes has argued, royal power and investiture provides a key paradigm for early Indic soteriology (Proferes 2007). ${ }^{39}$ Significantly, a synonym for dharmameghabhūmi in the Daśabhūmikasūtra is abhișekabhūmi. The abhișekabhümi was used to explain the Buddha as the Dharmarāja (king of dharma) in the final birth of a bodhisattva. ${ }^{40}$ One can suggest that archaic Vedic metaphors, such as the

\footnotetext{
36 Jamspal et al. discuss the variations between the Sanskrit and Tibetan text in this instance and opt for a 'middle way' translation between the two (Jamspal et al. 2004, $135 \mathrm{fn} \mathrm{35).}$

37 As atmospheric heat causes raindrops, so ritual asceticism (either by the priest or the ascetic) causes sweat, regarded as a 'homologue of the raindrops' (Kaelber 1989, p. 145). Also, see Kaelber 1989, pp. 19-20 for examples of ascetic mantra and food practices to generate rain.

38 The meaning of the root $\sqrt{s i c}$ is 'to pour out' or 'to sprinkle'.

39 For a discussion of the intersection of fire, water, and light in Vedic metaphors of sovereignty, see Proferes (2007, pp. 77-113).

40 In Buddhism, the abhiṣeka rite formed a central part of early Buddhist mythology and ritual, used to describe the exalted position of cakravärtin, the universal ruler of Buddhist mythology (Davidson 2002, p. 186).
} 
abhravarșa of soma, could have formed the basis for the Buddhist elaborations of dharmavarșa, ${ }^{41}$ dharmameghavarșa ${ }^{42}$ and dharmameghabhūmi ${ }^{43}$ Therefore, although the early classical context for the technical term dharmamegha is, as far as we know, Buddhist (and specifically early yogācāra within Mahāyāna), the Buddhists themselves were, most likely, drawing on earlier Vedic images of fertility and cosmogony in the abhișeka of the king.

To sum up so far, neither dharmameghadhyāna nor dharmameghasamādhi appear in the Buddhist sources that I have examined; rather, we find the compound dharmameghabhūmi in the Mahāyāna literature. However, given that the depiction of dharmameghabhūmi in the Yogaācārabhümiśāstra contains elimination of the kleśas, the attainment of infinite knowledge, and is related to ultimate samädhi, it is reasonable to make a link to the other dharmamegha that shares these features- that of Patañjali. However, in contrast to the qualitative abundance and the abundant quality of the Buddhist dharmamegha, Patañjali's metaphor is fairly devoid of qualities.

\section{The Revision of a Superlative Metaphor}

Drawing on conceptual metaphor theory, I will now present four different analyses that can each, in part, account for Patañjali's unique treatment of the term dharmamegha in relation to Buddhist sources.

\section{Dharmamegha as a Dead Metaphor}

One argument that can explain the two variant metaphorical treatments of dharmamegha in yoga and yogācāra is that of the standard distinction between creative and commonplace (dead) metaphors, underpinned by a passage of time. Dead metaphors are those that have been divorced from their original domain associations over time and have simply become a name or semantic placeholder for a thing or state. $^{44}$ Interpreting a dead metaphor ${ }^{45}$ effectively becomes

\footnotetext{
${ }_{41}$ In the Saddharmapuṇ̦arīkasūtra, as discussed above in "Saddharmapuṇdarīkasūtra and Daśabhūmikasūtra" section.

42 The Mahāyāna Gandavyūha, the $39^{\text {th }}$ chapter of the Avatamsakasūtra (from the early CE and which also contains the Daśabhūmikasūtra), refers to the dharmameghavarșa: yogācārānāạn bodhisattvānām sarvadharmasvabhāvatalanirghoșam nāma dharmameghavarșam (Suzuki and Idzumi 1934: 94.13-14). Due to the constraints of this study, I have been unable to consult this text, but it would make another interesting point of investigation for future research.

43 Indeed the Apadāna refers to the Vedic god of rain, Parjanya, in relation to dhammamegha e.g. Apadāna, Therāpadāna 54.530.4; Lilley (1925-1927, Part 2: 468). See footnote 21 in this article.

44 Creative metaphors are those that are generated in a present and 'live' context, while commonplace (or dead) metaphors are those that have become 'lexicalised' or 'conventionalized' through repeated use over time, and so no longer have a conceptual link to the original metaphoric context. These commonplace metaphors become so engrained in our thinking that we no longer notice them. The linguistic expressions 'a local branch of this organisation' and 'cultivating business relationships' draw on tree and agriculture metaphors, while 'the workings of the mind' draws on the metaphor of the mind as a machine. These dead metaphors are so far removed in time from the historical contexts in which
} 
disambiguation. It is possible that by the 4th century $\mathrm{CE}$, the original domain qualities of the Buddhist term dharmamegha had been 'forgotten' by Patañjali (as they would be eventually by Patañjali's sub-commentators; see below). This would suggest a passage of time from the Buddhist 'active' generation of dharmamegha to Patañjali's 'dead' usage. According to this argument, by the time of the Pātañjalayogaśāstra, dharmamegha was a moribund metaphor and not much more than a 'label', abstracted from its metaphorical context. However, given the approximate and close datings of the main texts under discussion here, ${ }^{46}$ this argument is not robust.

\section{Patañjali's Paralogical Metaphor: The Raincloud Without Any Rain}

Conceptual metaphors are informed by processes of reasoning: not only can conceptual metaphors be driven by analogical reasoning (in the mapping from the source to the target domain), but they are often underpinned by syllogistic structures of deductive reasoning and are therefore subject to logical entailment. Metaphors, then, have their own logical entailments, ${ }^{47}$ partly determined by the sensori-motor experience of the world we live in. ${ }^{48}$ For example, the logical entailments of a cloud are qualities such as 'spatially elevated, water-producing, visible, etc.' and not 'bright green, underground, and made of bricks'. The metaphorical application of 'cloud' has to be consistent with real-world experience and also has to be internally

Footnote 44 continued

they were created that they are no longer perceived as metaphors but, rather, as literally descriptive language.

45 Let us briefly review the compound dharmameghabhūmi as a multi-layered commonplace (or dead) metaphor in itself. To start with, of the three primary meanings of dharma, 'cosmic building block' and 'body of teaching' are both metaphorical. In contrast, 'religious conduct or virtue' is more descriptive. Moreover, the layers of metaphor in the Buddhist concept of dharmameghabhümi appear to denote temporal/chronological stratification. There are at least three distinct metaphorical layers: the cloud (megha), the level/foundation or ground (bhümi), and dharma itself, which is also arguably a metaphor. Dharmameghabhümi is certainly a mixed metaphor: how can a cloud be a foundation or ground? Ironically, even as it becomes doctrinally important as the xenith, dharmamegha is already approaching the status of a commonplace metaphor by the early Mahāyāna period: since it is blended with the metaphor of bhumi, the (earthly) foundation of the cloud of dharma is paradoxical to its core, entailing as it does that a cloud is an earthly stage. This is one paradox that Patañjali avoids; by linking dharmamegha to the more abstract terms of dhyāna and samādhi, he does not suggest that dharmamegha is also an earthly foundation. Patañjali's dharmamegha remains abstract and aloft.

46 As discussed in the introduction, the likely dating for the early 'proto' layers of the Yogācārabhümiśästra is c. 2nd century CE with a final redaction in the $4^{\text {th }}$ century CE, and the dating for the Pātañjalayogaśāstra is c. 4th century CE.

47 Here is an example of a syllogistic structure that produces the conceptual metaphor LOVE IS THE WIND:

Emotions are forces

Love is a natural force

[Therefore] Love is the wind

48 If we accept that metaphors are cognitive, they are largely determined by sensori-motor experiences, and thus the logic of bodily processes is carried over into metaphors and applied to abstract conceptual domains. '[I]mage-schemas, which arise recurrently in our perception and bodily movement, have their own logic, which can be applied to abstract conceptual domains. Image-schematic logic then serves as the basis for inferences about abstract entities and operations' (Johnson 2005, p. 24). 
logical (non-contradictory) in terms of the qualities it represents (i.e. in reality a cloud cannot be thunderous and fluffy at the same time). Yet some metaphors do operate on the basis of contradiction. ${ }^{49}$ Therefore, the term 'paralogical' is apt to describe a metaphor in which there appears to be 'a logical conflict of central meanings' (Kamber and Macksey 1970, p. 871). ${ }^{50}$

Functionally, Patañjali's dharmameghasamādhi closely resembles the Buddhist dharmameghabhümi as a superlative state: it is the goal of practice that provides endless knowledge and ultimate liberation. However, Patañjali strips back the metaphoric content of the Buddhist dharmamegha, so that the conceptual significance of the cloud is quite different; whereas the Buddhist cloud of rain primarily represents cultivation of growth, Patañjali's cloud represents cessation of growth. In mapping the qualities of megha to the domain of liberation, Patañjali selectively edits the qualities in order to revise the dharmamegha metaphor for polemical effect.

As we saw in "Saddharmapuṇdarīkasūtra and Daśabhūmikasūtra" and "Dharmameghabhūmi in the Yogācārabhūmiśāstra" sections, in the early Mahāyāna context dharmamegha was an elaborate metaphorical cluster to indicate vastness, abundance, a higher state, nectar from 'above', the cooling and extinguishing of flames of affliction, and primarily the stimulation of roots of virtue to sprout, grow, and ripen. The image of the cloud is effective in this context because it is interwoven with the image of water as 'rain' or 'ocean'. Notably, the flow of abundance is in two directions, from above (from the cloud to the ocean or earth) and from below (from the ocean to the cloud). This reflects the bodhisattva emphasis on 'cascade' teaching (sharing knowledge), in which the bodhisattva receives the rain of knowledge from the tathägatas and then, in turn, rains knowledge to mortals.

In the Pātañjalayogaśasstra, however, there is no such description of what the cloud of dharma contains, no image of a 'rain of abundance' or an 'ocean of knowledge'. It is as though the name 'dharmamegha' is co-opted from Buddhist sources, abstracted for its symbolic or functional value, and divested of its obvious metaphoric content. But perhaps it is the very sparseness of Patañjali's image that is itself most interesting, because it contains a logical twist. Patañjali's inclusion of the term dharmamegha, if indeed it is co-opted, may be an active critique of the 'other school' of yoga, the rival yogācāra. Patañjali, then, not only divests dharmamegha of its qualitative content, but also subverts its metaphoric logic, or entailments - and hence conceptual power-by imbuing it with the notion of lack rather than abundance. Far from expressing fecund growth by nurturing and cultivating the seed, Patañjali's dharmamegha samādhi is nirbīja samādhi, the state in which all traces of the seed of future kleśa have been eradicated. Here, the cloud of dharma

\footnotetext{
49 Conceptual metaphor theory accounts for contradiction within metaphors by means of the mechanism of selective editing (highlighting and hiding qualities). It accounts for contradictions in a conceptual scheme by demonstrating that apparently contradictory metaphors can share entailments.

50 Elsewhere, Beardsley used the term 'paralogical' to describe metaphors that bear no trace of similarity; they are like idioms that cannot be explained, only learnt (Beardsley 1958).
} 
presides over the negation of the seed, and the goal is to cut any growth by root and branch:

tallābhād avidyādayah kleśāh samūlakāṣam kaṣitā bhavanti kuśalākuśalāś ca karmāśayāh samūlaghātam hatā bhavanti

(PYŚ 4.30; Āgāśe 1904, p. 202)

From attaining that (dharmamegha), the kleśas of avidyā etc. are cut by root and branch and the karmic substrata, good and bad, are destroyed utterly.

Hence Patañjali's dharmamegha metaphor is a raincloud without any rain.

The cessative and negating functions ${ }^{51}$ of Patañjali's dharmamegha are continued in the interpretations of the sub-commentaries. It is worth reviewing these in brief, since they amplify the logical entailments of Patañjali's metaphoric treatment of dharmamegha. In the earliest commentary on the PYŚ, the c. 8thcentury Yogasütrabhāsyavivarana, ${ }^{52}$ Śankara does not elaborate on YS 4.29 (the only sütra to refer to dharmamegha), but does explain the term as the maturing of correct vision. ${ }^{53}$ Yet the Vivarana to YS 4.30-31 carries a set of interesting metaphoric entailments that belong to the cloud of dharma. Overall, Śankara's treatment of dharmamegha continues Patañjali's spartan presentation to elaborate a further act of qualitative erasure, one that is progressively unfolded.

While Patañjali abstracts the raincloud image to divest it of rain, thus committing a logical inversion ${ }^{54}$ of the original metaphor, Śankara takes this process several steps further. He describes a rain of negation, rain as ontological isolation, an impotent ocean, and the eventual erasure of the cloud itself. Let us now look at how he does this:

1. Firstly, Sankara reinstates the image of rain in the cloud metaphor: 'Its name is dharmamegha because it rains the utmost dharma called kaivalya (isolation)' 55

\footnotetext{
${ }^{51}$ We must be clear that Patañjali does not map the potential negative qualities of a cloud, such as 'gloomy' or 'destructive'. Patañjali's dharmamegha has a negating function but is not a negative image in itself, being a superlative attainment.

52 The arguments as to whether or not the Vivarana can be attributed to Śankara and dated this early are both controversial. For the claim that the Vivarana was a c. $8^{\text {th }}$-century composition by Śankara, see Leggett (1990) and Harimoto (2014). For the counterargument that the text is as late as the 11th-14th century, see Gelblum (1992), Rukmani (2001), and Larson and Bhattacharya (2008).

53 tasya dharmameghanāmnah samādheh samyagdarśanapākābhirūpasya (Viv. 4.30; Sastri and Krishnamurthi 1952, p. 363).

${ }^{54}$ The logical inversion of a metaphor is to render its conventional meaning antonymic by using selective editing (highlighting and hiding) to map qualities that contravene a conventional semantic field. Thus in the Buddhist metaphor 'liberation is a raincloud', the properties of the raincloud are mapped to the domain of spiritual liberation-following the convention that a raincloud is good because it provides abundant rain. In Patañjali's metaphor this conventional meaning is logically inverted to claim that a raincloud is good because it has no rain.

${ }^{55}$ kaivalyākhyam param dharma varșatīti dharmameghah iti saṃjñā (Viv 4.29; Sastri and Krishnamurthi 1952, p. 363).
} 
2. The rain, according to Śankara, is the dharma of kaivalya (isolation)—which denotes dharma as an ontological state. ${ }^{56}$ In Sāmkhya, this ontological state of kaivalya is characterized by subtraction (of the material world from consciousness, which is separate) rather than abundance (in the material world). This contrasts with the Buddhist rain of infinite abundance.

3. Next we encounter an image of a body of water. Śankara likens sattvic knowledge (the highest form of knowledge in the material realm) to an ocean, which brings to mind the ocean of knowledge of the Daśabhümikasütra. However, unlike that image, Śankara's image of the ocean is one that is devoid of potency because it is a great ocean (mahodadhi), motionless (nistaramga), isolated, unchangeable (avikriya), still, empty, not capable of perceiving anything.

4. Finally, the resulting state of sattva is as if the sun stands in the middle of a clear sky with all clouds vanished (Viv 4.31). ${ }^{57}$ (Viv 4.31; Sastri and Krishnamurthi 1952, p. 365).

Here we see the active erasure of the cloud image itself. In Śankara's final interpretation, the cloud has been dispelled. ${ }^{58}$

In his explication of dharmamegha, Śankara steers Patañjali's process of negation to its logical conclusion, so that dharmamegha becomes a cloud of dharma without a cloud.

Although it is beyond the scope of this study to fully consider later historical commentaries, it is interesting to note that the subsequent medieval sub-commentators appear to have followed Śankara's interpretation of dharmamegha to mean 'absence of cloud'. In the 10th-century Bhojarāja's Rājamārtanda connects dharmamegha to Patañjali’s image of irrigation (PYŚ 4.3) and follows Śankara's reading of dharmamegha as resulting in a sky that is free from clouds (Mitra 1883, pp. 203-204). Vācaspatimiśra (circa 10th century) elaborates further on the metaphor by asserting that a cloud-free sky increases available light: 'For just as in autumn when the rays of the moon are freed from a dense veil [of cloud], and when they are brilliant in all directions, the light is so endless.' This light leads to endless knowledge (Woods 1914 , p. 342). ${ }^{59}$ Śankara thus initiates a change in the primary metaphoric function of dharmamegha from water-producing to light-producing, and this interpretation is consolidated in the commentaries of Bhojarāja and Vācaspatimiśra. In these medieval sub-commentaries, the original metaphoric import of dharmamegha as a positive image has been forgotten to such a degree that the cloud becomes the obstacle to the light, the factor that obscures knowledge, rather than the

\footnotetext{
56 My understanding of Sāṃkya's kaivalya is that it is not just an epistemological distinction but ultimately an ontological one (i.e. one resides in the state of purusa).

57 aśeșajñeyavișayatvamambaratalamadhyavartino jaladharanirodhanirgatasya kheriva

58 Jacqueline Suthren-Hirst has pointed out the potentially positive value of the sky with a vanishing cloud (as in a pleasant post-rain state) (personal communication 2.7.2018). It is worth emphasizing again my differentiation between negative and positive 'values' and 'functions' in these literary descriptions (see above).

59 yathā hi śaradi ghanapațalamuktasya caṇ̣̂ārciṣah paritah pradyotamānasya prakāsānantyāt prakāśyā ghațādayo+alpāh prakāśante, evam apagatarajastamasaś cittasattvasya prakāśānantyād alpam prakāśyam iti (Tattvavaiśaradī 4.31: Āgāśe 1904, p. 203, lines 17-19)
} 
producer of knowledge as rain. However, this trend does not continue consistently. In the circa-14th-century Pañcadasí, an introduction to Vedānta, the author describes dharmamegha in terms resonant of the early Mahāyāna texts: 'The experts of yoga called this samādhi the cloud of dharma, since it rains an immeasurable downpour of the nectar of dharma. ${ }^{60}$ And, indeed, the last of the classical commentators, the 15th-16th-century Vijñānabhikṣu, also re-establishes the centrality of water to the metaphor in the form of rain: dharmamegha is so-called because it rains or pours down the dharma that completely destroys the remainder or root of all afflictions and actions. ${ }^{61}$ With the exception of the Pañcadaśi, the train of medieval commentarial revisions ${ }^{62}$ sustains Patañjali's treatment of dharmamegha as a negating principle. ${ }^{63}$

According to this line of analysis, Patañjali's dharmamegha is a polemical revision of a core Mahāyāna metaphor; Patañjali grafts the signature Buddhist term dharmamegha onto his own Sāmkhya-inflected system in full knowledge of its flagrant polemic effect. The significance of inverting the metaphoric value reflects that he is also inverting its soteriological value: Patañjali takes the abundantly rainfilled dharmamegha that symbolizes social sharing and converts it to an empty dharmamegha that symbolizes internal cessation. With its emphasis on teaching for the benefit of all humankind, Buddhist dharmamegha thus stands in stark contrast to the Sāmkhya ontological divorce from the material world. ${ }^{64}$ Given that the cooption of terms and concepts was common between rival religious groups in the classical period, the argument that Patañjali's dharmamegha was an intentional paralogical revision of metaphor is a strong one. ${ }^{65}$

\footnotetext{
${ }^{60}$ dharmamegham imam prāhuh samādhim yogavittamāh / varșaty eșa yato dharmāmrtadhārah sahasraśah // (Pañcadaś̄i I.60; cited in Bagchi 1967, p. 22). For a discussion of the authorship and provenance of the Pañcadaśt, see Fort (1998, pp. 114-115).

${ }^{61}$ kleșakarmādīnām nihśeșenonmulakam dharmam mehati varșatīti dharmameghah (Yogavārttika 4.29; Rukmani 1981-1989, 4: 122).

${ }^{62}$ Due to constraints of space, I have limited further investigation of the historical treatment of dharmamegha in the medieval period, but it would be an interesting topic for enquiry.

${ }^{63}$ Outside of the Brahmanical textual tradition, however, dharmamegha appears to have been associated with Patañjali. In c. 8th century CE, the Jain author Haribhadra Virahānka produced several important texts on yoga: in Sanskrit the Yogabindu (with auto-commentary) and the Yogadrsțisamuccaya, and in Prakrit the Yogavimśika (with a Sanskrit auto-commentary) and the Yogaśataka. Yaśovijaya's 17thcentury commentary on the Yogavimsika refers to dharmamegha as the name applied by those who follow Patañjali to the state of cognitive cessation (ayam ca dharmameghah iti pātañjalair gìyate) (YV 20). It is even described in terms of the burnt seed of vrtti (vrttibijadāha) -indicating that the soteriology of Patañjali was very much associated with the two metaphors of the burnt seed and the cloud of dharma. (For more on the burnt seed image, see O'Brien-Kop 2017).

${ }^{64}$ This may also be a trace of the Brahmanical soteriology of apophasis (negative theology): that the ultimate principle, brahman, cannot be understood via presence but only inferred via absence.

65 We must also consider that the logical inversion of dharmamegha is not the only polemical instance in the PYŚ. There are at least two other critiques of specifically Mahāyāna doctrines. The first is the explicit rejection of the cittamātra (mind-only) position in the fourth pāda (PYŚ 4.14-23), a doctrine associated with Yogācāra. The second example is Patañjali's description of the pleasures of heaven (PYŚ 3.51), which appears to undermine Mahāyāna concepts. The false promises of the gods to lure the yogin to heaven include divine sight and hearing (divye śrotracakșuși) and obtaining a diamond-like body (vajropamah kāya), These are both familiar motifs used to describe the bodhisattva in the Śrāvakabhümi and in the Bodhisattvabhümi, where they characterise dharmameghabhumi: the bodhisattva is described
} 


\section{Dharmamegha as Cessative Liberation}

According to this third argument, Patañjali's dharmamegha does not carry entailments that contradict Buddhist soteriology, but rather dharmamegha is logically concordant with a slightly variant scheme in the Yogācārabhūmiśāstra, in which the superlative state on the path to liberation is not 'abundance' but 'cessation'.

There is a least one description in the Yogācārabhümiśāstra that comes close to representing dharmamegha in terms of cessation. In the Samdhinirmocanasūtra, ${ }^{66}$ the seventh ${ }^{67}$ chapter refers to the ultimate form of yoga discipline, which is Buddhist yoga. This chapter contains the ten bhumis that we find in the Daśabhümikasūtra, with dharmamegha as the tenth stage. However, it also includes an 11th bhümi beyond the 10th to represent the superlative state, tathägatabhümi, 'the stage of realization of enlightenment' (Cleary 1995, p. 62). ${ }^{68}$ As in the Daśabhūmikasūtra and the Bodhisattvabhümi, the Samdhinirmocanasütra's description of dharmamegha is a cloud of vast expansion, conveying a sense of infinitude (SNS 7; Cleary 1995, p. 72). ${ }^{69}$ However, dharmamegha is now separated from the bodhisattvabhümi, which replaces it as the superlative state. This innovated 11th stage is a state of permanent cessation, and the qualities mapped to this bhimi express negating functions: the elimination of the kleśas, non-attachment, and non-

\section{Footnote 65 continued}

as having a vajropamah samädhi (e.g. BoBh 3.6; Wogihara 1930-1936, p. 405, line 16), and the acquisition of the divine ear and sight are the core elements of the fivefold divine powers obtained on the path. These two powers also appear in the third pāda of the PYŚ in the list of the siddhis. It seems that the 'celestial gods' are being used as a vehicle in which to critique the faulty promises of the Buddhists. The diamond body or diamond samādhi is an important metaphor in both Sarvāstivāda and Mahāyāna soteriology (Buswell 1989, pp. 104-114). The vajropamasamādhi is the culmination of the bhāvanāmārga in the Sarvāstivāda path scheme (Gethin 2007, p. 337). And in the Lañkāvatārasūtra, for example, the $10^{\text {th }}$ stage of dharmamegha is superceded by an ultimate eleventh stage (see "Dharmamegha as Cessative Liberation" section in this article), the tathāgatabhūmi, in which the last subtle remnants (that remain at the 11th stage)—cognitive hindrance (jñeyāvaraṇa) and afflictive hindrance (kleśāvaraṇa)—are completely eradicated by the diamond-like samādhi. Although Patañjali's text does not show awareness of this superlative level of the diamond samādhi, he does discuss the diamond form of the body: rūpalāvanyabalavajrasamhananatvāni kāyasampat darśanīyah kāntimān atiśayabalo vajrasamhananaś ceti. (PYŚ 3.46; Āgāśe 1904, p. 165) 'Perfection of the body is beauty of form, strength and diamond hardness. And it is made to appear as beautiful, unsurpassed in strength, and diamond-hard.' Interestingly Śankara does not comment on this sütra. However the bhāṣya commentary to the preceding sütra describes the body in terms of hardness - although it does not use the term 'diamond'. The 'perfections are the body' and 'the earth with its hardness does not oppose the movements of the yogin, for his body can penetrate even rock; waters with all their wetness do not moisten the yogin; fire does not burn him with its heat, nor does the wind which makes all bow, move him; in space, which by nature obstructs nothing, he becomes hidden, becoming invisible even to perfected beings' (trs. Leggett 1990, p. 349). This passage, of course, is referring to the five elements.

66 This is an independent text that is embedded in the supplementary section of the Yogācārabhümiśāstra.

67 Depending on the critical edition that one consults, this can be the seventh or eighth chapter.

68 We also find this scheme in the Lankāvatārasütra, in which the 10th stage of dharmamegha is superceded by the eleventh stage, the tathägatabhümi (see footnote 65).

69 'The tenth stage is called cloud of teaching because the gross body is as vast as space and the spiritual body is fulfilled, like a great cloud that can cover all' (trs. Cleary 1995, p. 72). Here, Cleary translates dharmamegha as 'cloud of teaching'. 
obstruction of realization (SNS 7; Cleary 1995, p. 72). From this observation, one can speculate that Patañjali's dharmamegha echoes not the Daśabhümikasūtra nor the Bodhisattvabhūmi but rather the Samdhinirmocanasütra by combining the 10th and 11th levels of attainment into a single concept: a dharmamegha that produces not abundance but cessation. ${ }^{70}$

In the Pātañjalayogaśāstra, dharmameghasamādhi is equated with seedless concentration (nirbija samādhi), which is the state of cessation of affliction (kleśanirodha) in which all traces of the seed of future kleśa have been eradicated (PYŚ 4.29). Generally in the PYŚ, the botanical image of the seed is one that is clearly framed in terms of non-germination. ${ }^{71}$ There is therefore no need of an image of 'rain' to accompany the seed, as this would in fact be counter-productive to the soteriological goal of the Pātañjalayogaśāstra. Within a soteriology of cessative liberation, then-possibly shared with texts such as the Samdhinirmocanasütra-Patañjali's dharmamegha is logically concordant, and its entailments are selectively edited to make it so.

In summary, this argument posits that Patañjali does not deliberately invert the metaphor for polemical effect, but is rather drawing on the Samdhinirmocanasūtra's version of dharmamegha, and-resonant of Buddhist Sarvāstivāda or Sautrāntika positions-constructs a concept of liberation as strictly cessative. Due to certain conceptual and discursive interconnections between the Pātañjalayogaśāstra and the Yogācārabhūmiśāstra, ${ }^{72}$ we cannot rule out this line of reasoning. However, given the relative paucity of information on the bhümis in the Samdhinirmocanasütra and the prevalence of theories of cessation in Buddhist literature as a whole, there would be no need to tie Patañjali's soteriology specifically to the Samdhinirmocanasūtra, rather than to any other Buddhist text from the early common era. The argument that Patañjali's dharmamegha draws on the SNS does not stand up to scrutiny.

There is, however, one further, and stronger, argument to be laid out in order to understand how Patañjali's dharmamegha relates to its contemporaneous Buddhist contexts.

\section{Factors of Literary Style: From Hyperbole to Understatement}

Patañjali's apparent inversion of the metaphoric value of dharmamegha may be a product of literary form. Literary style itself not only affects the way metaphors are employed but it can also amplify doctrinal difference. The richly evocative cosmological descriptions of Mahāyāna Buddhist treatises co-evolved with the invention of writing (Harrison 2003), whereas Brahmanic śāstras are a more faithful

\footnotetext{
70 Schmithausen has pointed out that the Daśabhūmikasūtra is older than the Samdhinirmocanasūtra (Schmithausen 2016, p. 401). Thus one can argue that Patañjali's text and the Samdhinirmocanasütra are both referencing older Sarvāstivādin yogācāra concepts of dharmamegha that may be grounded in Sautrāntika thought regarding the permanent negation of the seed and all its carriers (O'Brien-Kop 2017).

71 In the PYŚ, the concept of kleśa is constructed using the botanical image of the seed that is sterileand this draws on technical specificities of Sautrāntika discourse, particularly those that feature in the Abhidharmakośabhāṣya (O’Brien-Kop 2017).

72 For further discussion see O’Brien-Kop (2018, Chap. 3).
} 
transmission of oral culture-Tubb and Boose describe the sütra format as 'essentially signposts in a line of oral argument' (Tubb and Boose 2007, p. 1). I suggest that since the descriptive structures of Mahāyāna Buddhist writing are more elaborate, they can more effectively exploit the literary potential of metaphors.

In the textual culture of early Mahāyāna, literary style became more complex and innovative than that of oral texts. ${ }^{73}$ Indeed, the invention of writing may have partly provided the impetus and vehicle for doctrinal developments in Buddhism that led to Mahāyāna. ${ }^{74}$ The Mahāyāna writers displayed specific literary techniques to hone and express doctrinal concepts: for example, conveying 'eternity' and 'infinity' through syntagmatic extension. ${ }^{75}$ As a result, the Buddhist accounts of dharmameghabhūmi in the Daśabhūmikasūtra and the Yogācārabhūmiśāstra are hyperbolic, so as to become almost almost unprocessable in the cognitive domain (Flores 2008, p. 14). In terms of source and target, the Mahāyāna literary style exaggerates the structure of metaphor, repeating and multiplying the qualities of the target domain to enhance meaning. Thus a basic doctrinal statement such as: 'The Buddha is infinite' becomes 'The Buddha is immeasurably infinite, projected across the sky a million trillion times, in countless infinite directions, in myriad images of forms upon forms for all eternities upon eternities, with innumerable qualities,' etc. ${ }^{76}$ This literary style is not just about embellishment. It is the use of particular literary devices to formally express the doctrine of infinitude: the layering of synonyms upon synonyms generates chains of signifiers that appear to be without end. Furthermore, the stylistic use of synonymic saturation is the doctrine of infinitude in experiential form for the text's consumer, whether through reading, listening, or imagining.

The Mahāyāna literary style contrasts significantly with the literary style of the Pātañjalayogaśāstra. The Brahmanical sūtra genre of compressed aphorisms ${ }^{77}$ belongs to oral textual culture and was designed for memorization. Hence, it is formally minimal. Patañjali's metaphor is only superlative, and is not linked to any numbered levels or stages of attainment, as in the Buddhist schemes. I propose that, by virtue of a literary style that rests on compression, Patañjali's dharmamegha is 'super-compressed' and takes all ten levels of the dharmameghabhümi scheme and squashes them into one. Synechdochally, dharmamegha is a part that stands in for the whole ${ }^{78}$ : the superlative stage in itself signifies the whole scheme of ten stages (and therefore dharmamegha stands in for the whole of spiritual cultivation or

\footnotetext{
73 On the relationship of early Buddhist Pāli canonical suttas to mnemonic functions in oral culture, see Allon (1997).

74 This thesis was put forward by scholars such as Harrison (2003), but has recently been refuted by Drewes $(2010,2018)$.

75 Collins uses the term 'infinite extension' (Collins 2010, p. 25) to describe the way in which eternity is portrayed or understood in Mahāyāna texts.

76 This is a paraphrase of typical literary style in the Daśabhūmikasūtra.

77 It has been argued that the word sutta in the Buddhist sutta genre was derived from Vedic sūkta (hymn) and not sütra (thread/aphorism), and so, like the süktas, the Buddhist sutta genre is characterised by extolment and hyperbole and not conciseness (e.g. Norman 2006, p. 135).

78 Synechdoche is a special instance of metonymy. In metonymy, one thing stands in for another, while in synechdoche, a part of one thing stands in for the whole of that thing.
} 
bhāvanā, as not just any part but the best part). For audiences in the living religiophilosophical communities of the 4th century CE, the context would have been obvious - that of the Buddhist scheme of the daśabhümis (the ten foundations or stages). Today's readers, however, have to painstakingly unpick the densely compressed threads of meaning. There is often an 'enigmatic' quality to a sütra text because so much is left unsaid (and without living oral transmission has been lost to history).

There is one other instance of understatement in Patañjali's dharmamegha. Patañjali describes the infinite knowledge of dharmamegha by referencing what is not accessed: the unaccessed knowledge is likened to fireflies in the sky (PYŚ 4.31). In Patañjali's image, the ineffability of infinite knowledge is not conveyed (as in the Mahāyāna texts) with metaphors of infinity but with a counter-intuitive simile of extreme finitude. The infinity of the knowledge gained is demonstrated negatively: that which remains unknown at the level of dharmamegha is like fireflies in the sky, i.e. insignificant. Although Patañjali's account of dharmamegahasamādhi shares a theory of infinite knowledge with the yogācāra attainment at dharmameghabhümi, the metaphor is framed in the negative. Such apophatic soteriology is reified by the compression of literary form, creating an ellipsis at the heart of the text.

There is one final aspect of paralogical revision, and it is a 're-vision': the inversion of the significance of the 'vision' of dharmamegha. Although the yoga and yogācāra presentations of infinite knowledge are framed differently, both accounts are anchored in the root metaphor of vision (KNOWING IS SEEING). ${ }^{79}$ The soteriology of Sāmkhya rests on the correct vision (i.e. knowledge) of the ultimate ontological distinction (puruṣa and prakrti). Equally, Mahāyāna visionary meditation gravitates around florid images of the Buddha. Yet these are two divergent notions of vision: Patañjali's vision of dharmamegha is the perception of an unseen reality (purușa), while the yogācāra vision is of the majestic spectacle of proliferating buddhas without end. It is, then, perhaps no surprise that underlying the construction of negative metaphors in Patañjali's text is a doctrine of negative vision: the goal of Sāmkhya is to see the unseen (the non-material).

Both the sūtra and the Mahāyāna śāstra formats gesture towards the ineffable. They simply do it in opposite ways: Patañjali approaches the ineffability of puruṣa through silence and apophasis, while the verbose proliferation of Mahāyāna texts signal that even an infinite number of synonymic descriptions could never suffice to express the unbounded state of Buddhahood. ${ }^{80}$ These issues of style both reflect and generate doctrinal differences between yoga and yogācāra. There appears to be no precedent in Buddhist thought for abstracting dharmamegha from the tenfold (or sometimes 11-fold) scheme of bhümis in order to treat it in isolation in a meditation

\footnotetext{
79 Cognitive metaphor scholars use these schematic phrases in capitals to denote a cognitive metaphor. As Gibbs explains: 'The schematic phrase LIFE IS A JOURNEY represents only a convenient summary description of the rich set of mental mappings that characterize the complex relationship between target (LIFE) and source (JOURNEY)' (Gibbs 2017, p. 18).

${ }^{80}$ Although bodhi is framed in this way in our selected Mahāyāna texts, earlier conceptions of nirvāna were apophatic. As we have noted, the very concept of nirvāna is itself constructed using the negative. The literal meaning of nirvāna is 'extinguished' or 'quenched', as in the notion of a fire quenched due to lack of fuel (Gombrich 1996, pp. 66-67).
} 
treatise. Thus Patañjali's appropriation of dharmamegha is already radical-in that he leaves behind the other nine steps and indeed the whole paradigm. If it is the case that Patañjali merely abstracts the superlative state, this is itself a hostile paradigmatic revision.

Lakoff and Johnson insisted that domain-mapping in metaphor could never be a totalising enterprise, or it would result in simple identification between two domains. Hence domain-mapping is always partial, in that there is selective editing (highlighting and hiding). Neither Patañjali nor the Mahāyāna scholars mapped all the qualities of a cloud to the theory of liberation. In order to make dharmamegha work at all, they had to exclude a whole host of other properties (e.g a cloud can also be gloomy, destructive, beyond reach, etc.). As we have seen, Patañjali's dharmamegha is more of a semantic placeholder than a 'productive' metaphor that maps domain qualities of rain, elevation, fullness, unattainability, ephemerality, abundance, etc. Indeed, Patañjali's metaphor contains little domain-mapping of qualities - most are hidden, and not highlighted.

\section{Conclusion}

By categorizing the Yogācārabhūmiśāstra as a yogaśāstra, I have put forward the necessity of considering that there were prior systems of non-Brahmanical yoga discipline to Pātañjala yoga. ${ }^{81}$ If Pātañjala yoga post-dates early yogācāra—and it most likely does — this strengthens the argument that Patañjali knowingly references key yogācāra paradigms.

In my concluding assessment, Patañjali's strikingly empty metaphor of dharmamegha is largely a result of literary style and polemical revision due to doctrinal necessity. It is not a result of deliberate harmonization with Mahāyāna soteriology (such as that of the Samdhinirmocanasūtra) nor due to the ambiguity of dead metaphor. Indeed, because of the specific use of the term dharmamegha in Buddhist texts from the 2nd-century CE onwards, it can be stated with some confidence that Patañjali adopts the term dharmamegha from the Buddhist conceptual sphere for polemical effect. The nature of this revision is paralogical; selective editing highlights the negating qualities of a raincloud to support a doctrine of apophasis and a soteriology of cessation, in line with Sāṃhya metaphysics. The revision of the dharmamegha metaphor was also compounded by factors of literary style, in particular the predominant feature of the Brahmanical sütra genre, compression. What is less easy to clarify is the exact Buddhist textual sources, debates or thinkers from which Patañjali may have drawn. However, due to their association of dharmamegha with yoga discipline (yogācāra), we can point to the early layers of the Yogācārabhümiśāstra (the Bodhisattvabhūmi and the Samdhinirmocanasūtra) and to the Daśabhūmikasūtra, all of which potentially

\footnotetext{
${ }_{81}$ There are other early systems to consider, such as the șadangayoga of the Maitri Upanișad (MU 61.8) in the early centuries of the Common Era, although the six stages are recounted in name only and not in detail.
} 
predate the Pātañjalayogaśāstra. ${ }^{82}$ This article has traced the metaphoric import of megha in dharmamegha, using conceptual metaphor theory, and also hopes to provide a fresh starting point for revisiting the meaning of dharma in dharmamegha.

Acknowledgements The author would like to thank Jacqueline Suthren-Hirst, Richard King, Rupert Gethin, Theodore Proferes, James Mallinson and participants at the 2018 Sanskrit Tradition in the Modern World Symposium for their valuable comments on earlier drafts of this paper. Any remaining errors are my own.

\section{Compliance with Ethical Standards}

Conflict of interest This author has no conflict of interests to declare.

Open Access This article is licensed under a Creative Commons Attribution 4.0 International License, which permits use, sharing, adaptation, distribution and reproduction in any medium or format, as long as you give appropriate credit to the original author(s) and the source, provide a link to the Creative Commons licence, and indicate if changes were made. The images or other third party material in this article are included in the article's Creative Commons licence, unless indicated otherwise in a credit line to the material. If material is not included in the article's Creative Commons licence and your intended use is not permitted by statutory regulation or exceeds the permitted use, you will need to obtain permission directly from the copyright holder. To view a copy of this licence, visit http:// creativecommons.org/licenses/by/4.0/.

\section{References}

\section{Primary}

Āgāśe, K. (Ed.). (1904). Vācaspatimiśraviracitațīkāsamvalitavyāsabhāṣyasametāni Pātañjalayogasūtrāṇi, Tathā Bhojadevaviracitarājamārtaṇ̣̂ābhidhavṛttisametāni pātañjalayogasūtrāṇi. sūtrapāṭhasūtravarṇānukramasūcībhyām ca Sanāthīkṛtāni. Poona: Ānandāśrama.

Angot, M. (trs.). (2012). Le Yoga-sutra de Patanjali. Le Yoga-Bhasya de Vyasa avec des Extraits du YogaVarttika de Vijnana-Bhiksu. Paris: Les Belles Lettres.

Bangali, B. (trs.). (1976). Yogasutra of Patanjali with the Commentary of Vyasa. Delhi: Motilal Banarsidass.

Belvalkar, S. (Ed.). (1954). The Sāntiparvan. In The Mahābhārata, For the First Time Critically Edited. Volume 14-16. Poona: Bhandakar Oriental Research Institute.

Cleary, T. (trs.). (1995). Buddhist Yoga. Boston: Shambala.

Edgerton, F. (trs.). (1965). The Beginnings of Indian Philosophy: Selections from the Rig Veda, Atharva Veda, Upanisads, and Mahābhārata. Cambridge, MA: Harvard University Press.

Horner, I. B. (trs.). (1963-1964). Milinda's Questions: Translated from the Pali. Sacred Books of the Buddhists (Vols. 22-23). London: Luzac.

Horner, I. B. (trs.). (1975). Chronicle of Buddhas (Buddhavamsa) and Basket of Conduct (Cariyāpitaka). Sacred Books of the Buddhists, Vol XXXI: The Minor Anthologies of the Pali Canon, Part III. London: Pāli Text Society.

Jayawickrama, N. A. (Ed.). (1974). Buddhavamsa and Cariyāpițaka. PTS text series (Vol. 166). London: Pāli Text Society.

Jamspal, L., Clark, R., Wilson, J., Zwilling, L., Sweet, M., \& Thurman, R. (trs.). (2004). The Universal Vehicle Discourse Literature (Mahāyānasūtrālaìkāra) by Maitreyanātha/Āryāsañga Together with its Commentary (Bhāssya) by Vasubandhu. Translated from the Sanskrit, Tibetan and Chinese. New York: American Institute of Buddhist Studies, Columbia University and Columbia University's Center for Buddhist Studies and Tibet House US.

\footnotetext{
82 Indeed, Patañjali may have had knowledge of other independent yogācāra texts in circulation, such as the Śrāvakabhūmi, the Bhāvanāmaȳ̄ Bhūmih or the early *Yogācārabhūmi of Sangharakṣa.
} 
Leggett, T. (trs.). (1990). The Complete Commentary by Sankara on the Yoga Sutras: A Full Translation of the Newly Discovered Text. London: Kegan Paul International.

Lévi, S. (Ed., trs.). (1907). Mahāyāna-sūtrālaṃkāra. Exposé de la Doctrine de Grande Véhicule. Paris: Libraire Honoré Champion.

Lilley, M. (Ed.). (1925-1927). The Apadāna of the Khuddaka Nikāya: Parts I and II. Oxford: Pali Text Society.

Olivelle, P. (trs.). (1998). The Early Upaniṣads: Annotated Text and Translation. New York: Oxford University Press.

Maas, P. (Ed.). (2006). Samādhipāda. Das erste Kapitel des Pātañjalayogaśāstra zum ersten Mal Kritisch Ediert. GeisteskulturIndiens. Texte und Studien (Vol. 9). Aachen: Studia Indologica Universitatis Halensis.

Mitra, R. (trs.). (1883). The Yoga Aphorisms of Patanjali: With the Commentary of Bhoja Raja and an English translation. Calcutta: Royal Asiatic Society of Bengal.

Rahder, J. (Ed.). (1926). Daśabhūmikasūtra. Leuven: JB Istas.

Rukmani, T. S. (trs.). (1981-1989). Yogavārttika of Vijñānabhikșu: Text, with English Translation and Critical Notes along with the Text and English Translation of the Pātañjala Yogasütra and Vyāsabhāṣya (4 vol). New Delhi: Munshiram Manoharlal.

Rukmani, T. S. (trs.). (2001). Yogasūtrabhāṣyavivaraṇa of Śañkara: Vivaraṇa Text with English Translation, and Critical Notes along with Text and English Translation of Patañjali's Yogasütras and Vyāsabhāsyya, Volumes 1 and 2. New Delhi: Munshiram Manoharlal Publishers Pvt. Ltd.

Sastri, R., \& Krishnamurthi, S. R. (Eds.). (1952). Pātañjalayogasūtrabhāṣya Vivaranam of ŚañkaraBhagavat Pāda. Madras: Government Oriental Manuscripts Library.

Stuart, D. (2015). A Less Travelled path: Saddharmasmrtyupasthānasūtra Chapter 2: Critically Edited with a Study on its Structure and Significance for the Development of Buddhist Meditation. Volumes 1 and 2. Beijing: China Tibetology Publishing House and Austrian Academy of Sciences Press.

Suzuki, D. T., \& Idzumi, H. (Eds.). (1934). The Gandavyuha Sutra. Kyoto: Sanskrit Buddhist Texts Publishing Society.

Trenckner, V. (Ed.). (1962). The Milindapañho: Being Dialogues between King Milinda and the Buddhist Sage Nāgasena. The Pāli Text. London: Pali Text Society, Luzac \& Company Ltd.

Vaidya, P. L. (Ed.). (1967). Daśabhūmikasūtra. Buddhist Sanskrit texts no. 7. Darbhanga: The Mithila Institute of Post-Graduate Studies and Research in Sanskrit Learning.

Walters, J. (trs.). (2017). Legends of the Buddhist Saints. Wala Wala: Jonathan S Walters and Whitman College.

Wogihara, U. (Ed.). (1930). Bodhisattvabhümi: A Statement of Whole Course of the Bodhisattva (Being Fifteenth Section of Yogācārabhūmi). Tokyo: Taisho College.

Wogihara, U., \& Tsuchida, C. (1934). Saddharmapuṇdarīka-sūtram. Tokyo: Bibliotheca Buddhica Publication.

Woods, J. (trs.). (1914). The Yoga-System of Patañjali [...] and the comment called Yoga-Bhāṣya attributed to Veda-Vyāsa and the explanation called Tattva-Vaiśāradī of Vācaspati Miśra. Cambridge, MA: Harvard Oriental Series.

Woodward, F. L., et al. (1973). Pāli Tipițakam Concordance (Vol. II). London: Pali Text Society London.

\section{Secondary}

Allon, M. (1997). Style and function: A study of the dominant stylistic features of the prose portions of Pāli Canonical Sutta texts and their mnemonic function. Studio Philologica Buddhica: Monograph series, XII. Tokyo: The International Institute for Buddhist Studies.

Bagchi, S. (1967). Introduction. In P. L. Vaidya (Ed.), Daśabhūmikasūtra. Buddhist Sanskrit texts no. 7. Darbhanga: The Mithila Institute of Post-Graduate Studies and Research in Sanskrit Learning.

Beardsley, M. (1958). Aesthetics: Problems in the philosophy of criticism. New York: Harcourt Brace.

Buescher, H. (2008). The inception of Yogācāra-Vijñānavāda. Vienna: Verlag der Österreichischen Akademie der Wissenschaften.

Buswell, R. (1989). The formation of Ch'an ideology in China and Korea: The Vajrasamädhi-Sūtra, a Buddhist apocryphon. Princeton, NJ: Princeton University Press.

Collins, S. (2010). Nirvana: Concept, imagery, narrative. Cambridge: Cambridge University Press. 
Conze, E. (1954). Buddhist texts through the ages. Oxford: Bruno Cassirer.

Davidson, R. (2002). Indian esoteric Buddhism: A social history of the tantric movement. New York: Columbia University Press.

Deleanu, F. (Ed.). (2006). The Chapter on the Mundane Path (Laukikamārga): A Trilingual Edition (Sanskrit, Tibetan, Chinese), Annotated Translation and Introductory Study (2 vol). Tokyo: International Institute for Buddhist Studies.

Demiéville, P. (1951). La Yogācārabhūmi de Sanggharakșa. Bulletin du l'École Française d'ExtrêmeOrient, 44(2), 339-436.

Drewes, D. (2010). Early Indian Mahāyana Buddhism II: New perspectives. Religion Compass, 4, 2.

Drewes, D. (2018). The Forest Hypothesis. In P. Harrison (Ed.), Setting out on the great way: Essays on early Mahāyāna Buddhism. Sheffield and Bristol: Equinox.

Edgerton, F. (1953). Buddhist hybrid Sanskrit grammar and dictionary. New Haven: Yale University Press.

Flores, R. (2008). Buddhist scriptures as literature: Sacred rhetoric and the uses of theory. Albany: SUNY.

Fort, A. (1998). Jivanmukti in transformation: Embodied liberation in Advaita and Neo-Vedānta. New York: SUNY.

Gelblum, T. (1992). Notes on an English Translation of the Yogasūtrabhāṣyavivarana. Bulletin of the School of Oriental and African Studies, 55(1), 76-89.

Gethin, R. (2007). The Buddhist path to awakening. Oxford: Oneworld.

Gibbs, R. (2017). Metaphor wars: Conceptual metaphors in human life. Cambridge: Cambridge University Press.

Gold, J. C. (2015). Paving the great way: Vasubandhu's unifying Buddhist philosophy. New York: Columbia University Press.

Gombrich, R. (1996). How Buddhism began: The conditioned genesis of the early teachings. London: Athlone.

Harimoto, K. (Ed.). (2014). God, reason, and yoga: A critical edition and translation of the commentary ascribed to Śankkara on Pātañjalayogaśāstra. Hamburg: University of Hamburg.

Harrison, P. (2003). Mediums and messages: Reflections on the production of Mahāyāna Sūtras. The Eastern Buddhist, 35, 1-2.

Johnson, M. (2005). The philosophical significance of image schemas. In B. Hampe \& J. Grady (Eds.), From perception to meaning: Image schemas in cognitive linguistics. Berlin: Mouton de Gruyter.

Kaelber, W. (1989). Tapta Mārga: Asceticism and initiation in vedic India. Albany: SUNY.

Kamber, G., \& Macksey, R. (1970). "Negative metaphor" and Proust's rhetoric of absence. Modern Language Notes, 85, 6.

Klostermeier, K. (1986). Dharmamegha samādhi: Comments on Yogasūtra IV, 29. Philosophy East and West, 36(3), 253-262.

Koelman, G. (1970). Pātañjalayoga: From related ego to absolute self. Poona: Papal Athenaeum.

Kövecses, Z. (2005). Metaphor in culture: Universality and variation. Oxford: Cambridge University Press.

Kövecses, Z. (2006). Language, mind, and culture: A practical introduction. London: Oxford University Press.

Kövecses, Z. (2015). Where metaphors come from: Reconsidering context in metaphor. Oxford: Oxford University Press.

Kragh, U. T. (2013). The foundation for yoga practitioners: The Buddhist Yogācārabhūmi treatise and its adaptation in India, East Asia, and Tibet. Harvard oriental series. Cambridge, MA: Harvard University Press.

Lakoff, G., \& Johnson, M. (1980). Metaphors we live by. Chicago: University of Chicago Press.

Lakoff, G. (1987). Women, fire and dangerous things: What categories reveal about the mind. Chicago: University of Chicago Press.

Lakoff, G., \& Turner, T. (1989). More than cool reason: A field guide to poetic metaphor. Chicago: University of Chicago Press.

Larson, G., \& Bhattacharya, R. S. (2008). Encyclopedia of Indian philosophies, Volume XII. Yoga: India's philosophy of meditation. Delhi: Motilal Banarsidass Publishers Private Limited.

Maas, P. (2010). On the Written Transmission of the Pātañjalayogaśāstra. In J. Bronkhorst \& K. Preisendanz (Eds.), From Vasubandhu to Caitanya: Studies in Indian philosophy and its textual history. Delhi: World Sanskrit. 
Maas, P. (2013). A Concise Historiography of Classical Yoga. In E. Franco (Ed.), Periodisation and historiography of Indian philosophy. Vienna: University of Vienna.

Maas, P. (2014). Sarvāstivāda Abhidharma and the Yoga of Patañjali. Paper presented at the 17th Congress of the International Association of Buddhist Studies, University of Vienna, Austria, August 18-23, 2014.

Malalasekera, G. P. (1938). Dictionary of Pāli Proper Names (Vol. 2). London: John Murray.

Norman, K. R. (2006). A philological approach to Buddhism. Lancaster: PTS.

O'Brien-Kop, K. (2017). Classical discourses of liberation: Shared botanical metaphors in Sarvāstivāda Buddhism and the yoga of Patañjali. Religions of South Asia, 11(2-3), 123-157. https://doi.org/10. 1558/rosa.37021.

O'Brien-Kop, K. (2018). Seed and cloud as metaphors of liberation in Buddhist and Pātañjala yoga: An Intertextual study. Unpublished $\mathrm{PhD}$ dissertation, SOAS University of London, UK.

Proferes, T. (2007). Vedic ideals of sovereignty and the poetics of power. New Haven, CT: American Oriental Society.

Rukmani, T. (2007). Dharmamegha-samādhi in the Yogasūtras of Patañjali: A critique. Philosophy East and West, 57(2), 131-139.

Sakuma, H. S. (2013). Remarks on the lineage of Indian Masters of the Yogācāra School: Maitreya, Asanga, and Vasubandhu. In U. T. Kragh (Ed.), The foundation for yoga practitioners: The Buddhist Yogācārabhümi treatise and its adaptation in India, East Asia, and Tibet. Cambridge, MA: Harvard University Press.

Schertzer, M. (1986). The elements of grammar. London: Collier Macmillan.

Schmithausen, L. (2016) Collected Papers Volume 1: 1963-1977. In: Deleanu, F. et al. (eds) Lambert Schmithausen: Collected papers, Volume 1 1963-1977. Studio Philologica Buddhica: Monograph Series, XXXIVa. Tokyo: The International Institute for Buddhist Studies.

Schopen, G. (2006). A Well-Sanitized Shroud: Asceticism and Institutional Values in the Middle Period of Buddhist Monasticism. In P. Olivelle (Ed.), Between the empires: Society in India 300 BCE to 400 CE. Oxford: Oxford University Press.

Silk, J. (2000). The Yogācāra Bhikșu. In Wisdom, compassion, and the search for understanding: The Buddhist studies legacy of Gadjin M. Nagao. Honolulu: University of Hawaii Press.

Skorupski, T. (2009). Clouds, their emotions and mysteries. In Z. de Weck (Ed.), Cloud choreography and other emergent systems. London: Parasol Unit/Koenig Books.

Tubb, G., \& Boose, E. (2007). Scholastic Sanskrit: A manual for students. New York: American Institute of Buddhist Studies, Columbia University.

Wujastyk, D. (2018). Some problematic yoga Sūtra-s and their Buddhist background. In K. Baier et al. (Eds.), Yoga in transformation: Historical and contemporary perspectives. Vienna: Vienna University Press.

Publisher's Note Springer Nature remains neutral with regard to jurisdictional claims in published maps and institutional affiliations. 